Prepared in cooperation with the Arkansas Natural Resources Commission and the Arkansas Geological Survey

\title{
Water Levels in Aquifers in the Nacatoch Sand of Southwestern and Northeastern Arkansas and the Tokio Formation of Southwestern Arkansas, Spring 2008
}

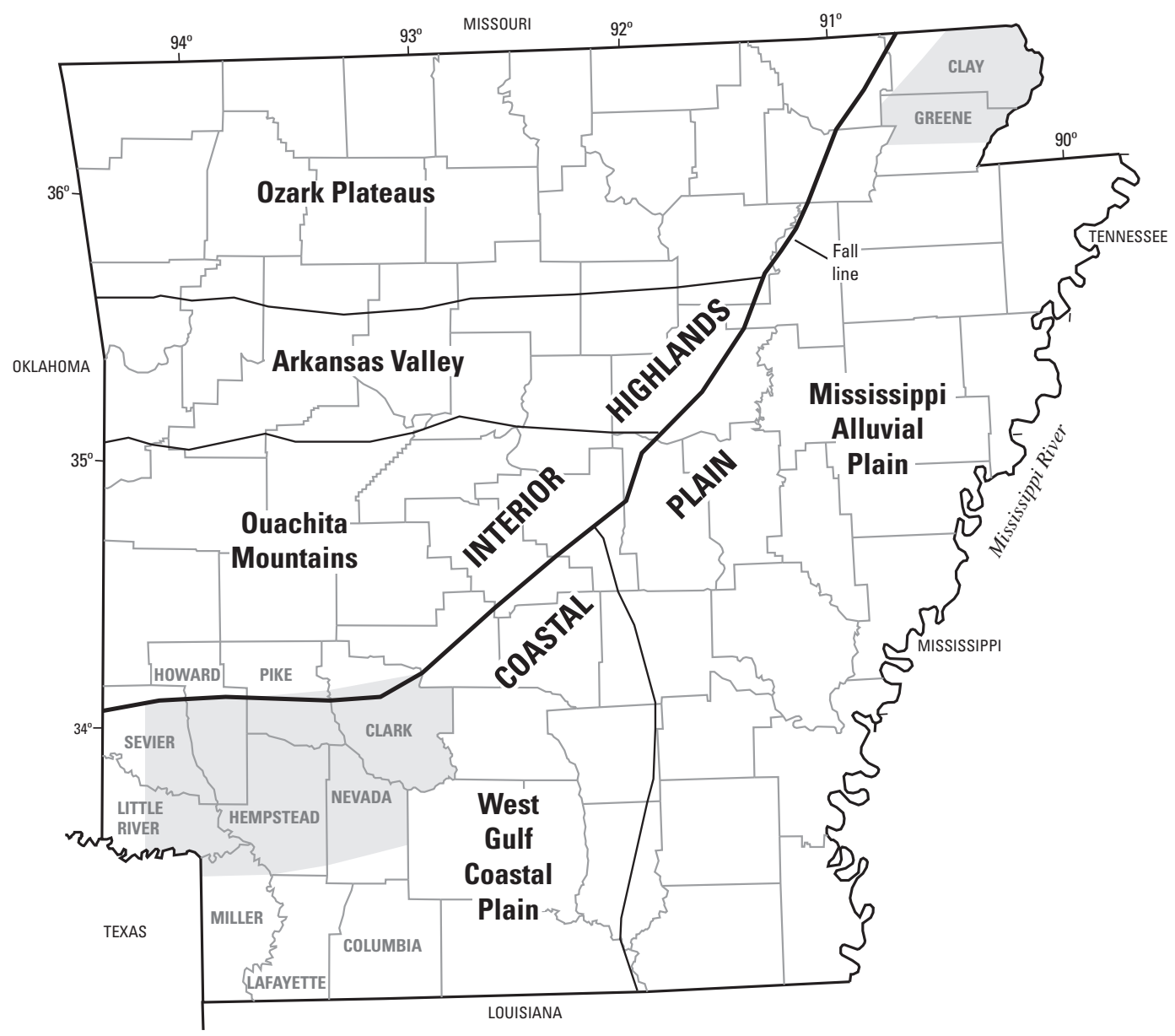

Scientific Investigations Report 2010-5238 



\section{Water Levels in Aquifers in the Nacatoch Sand of Southwestern and Northeastern Arkansas and the Tokio Formation of Southwestern Arkansas, Spring 2008}

By T.P. Schrader and Joshua M. Blackstock

Prepared in cooperation with the Arkansas Natural Resources Commission and the Arkansas Geological Survey

Scientific Investigations Report 2010-5238 


\section{U.S. Department of the Interior \\ KEN SALAZAR, Secretary \\ U.S. Geological Survey \\ Marcia K. McNutt, Director}

U.S. Geological Survey, Reston, Virginia: 2010

This and other USGS information products are available at http://store.usgs.gov/
U.S. Geological Survey
Box 25286 , Denver Federal Center
Denver, CO 80225
To learn about the USGS and its information products visit http://www.usgs.gov/
1-888-ASK-USGS

Any use of trade, product, or firm names is for descriptive purposes only and does not imply endorsement by the U.S. Government.

Although this report is in the public domain, permission must be secured from the individual copyright owners to reproduce any copyrighted materials contained within this report.

Suggested citation:

Schrader, T.P., and Blackstock, J.M., 2010, Water levels in aquifers in the Nacatoch Sand of southwestern and northeastern Arkansas and the Tokio Formation of southwestern Arkansas, spring 2008: U.S. Geological Survey Scientific Investigations Report 2010-5238, 22 p. 


\section{Contents}

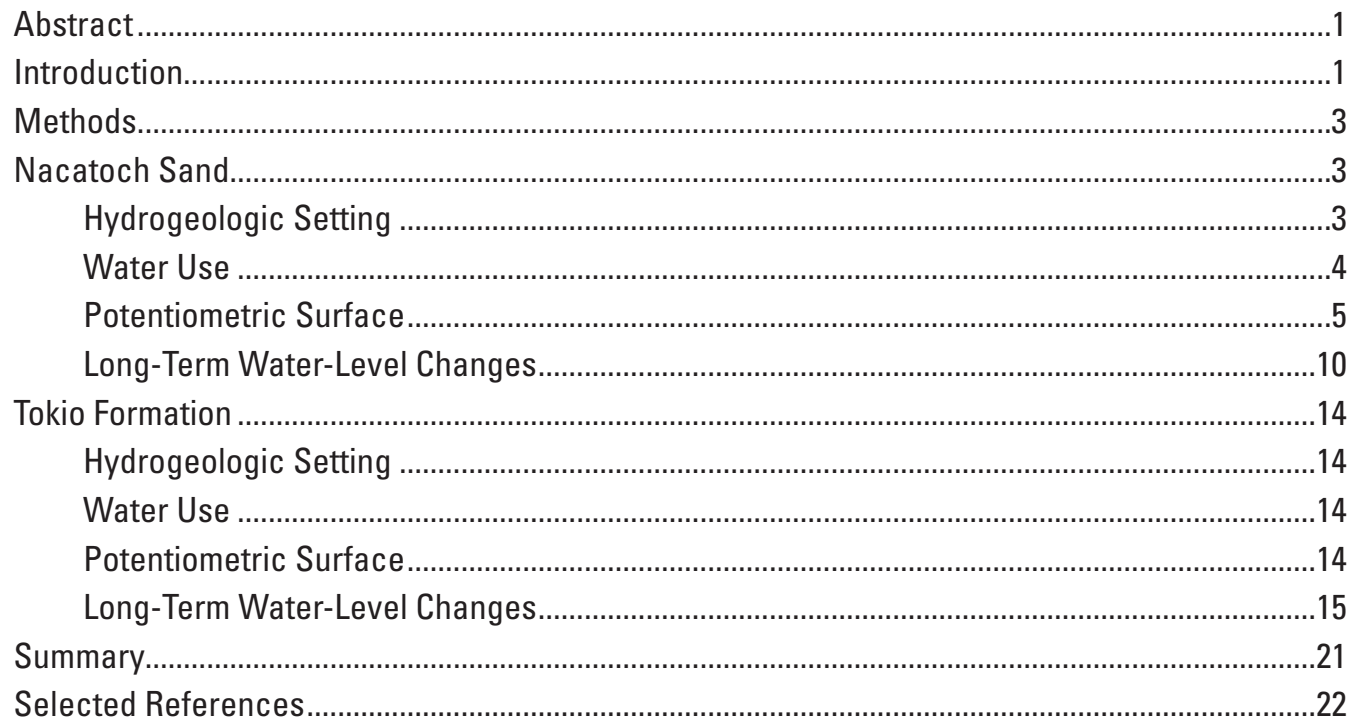

\section{Figures}

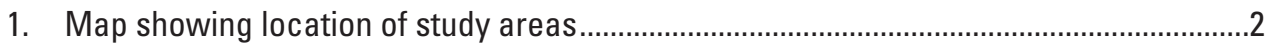

2. Diagram showing well-numbering system...................................................................

3. Graph showing withdrawals for the Nacatoch aquifer for the northeastern area in

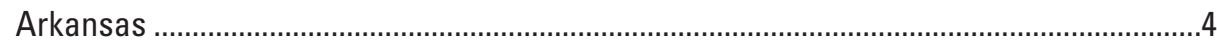

4. Graph showing withdrawals for the Nacatoch aquifer for the southwestern area in

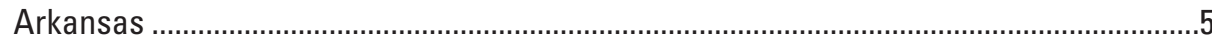

5. Map showing potentiometric surface of the Nacatoch aquifer, northeastern

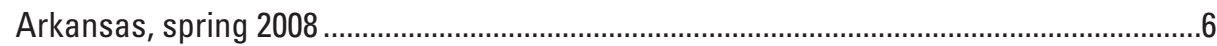

6. Map showing potentiometric surface of the Nacatoch aquifer, southwestern

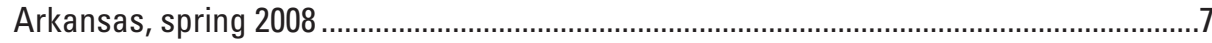

7. Water-level hydrographs (A to F) for selected wells completed in the Nacatoch

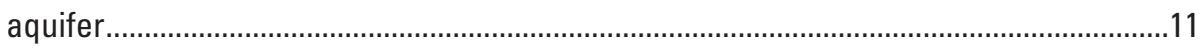

8 Graph showing withdrawals for the Tokio aquifer for the southwestern area

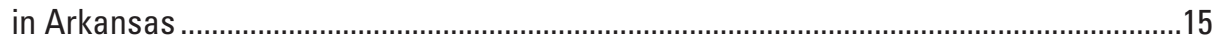

9. Map showing potentiometric surface of the Tokio aquifer, southwestern

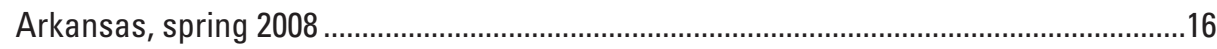

10. Water-level hydrographs ( $\mathrm{G}$ to $\mathrm{J}$ ) for selected wells completed in the Tokio aquifer.....19 


\section{Tables}

1. Water-level data collected during spring 2008 from wells completed in the

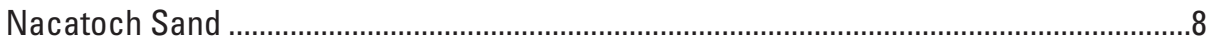

2. Water-level data collected during spring 2008 from wells completed in the Tokio Formation

\section{Conversion Factors Vertical Datums, and Abbreviations}

\begin{tabular}{lll}
\hline \multicolumn{1}{c}{ Multiply } & \multicolumn{1}{c}{ By } & \multicolumn{1}{c}{ To obtain } \\
\hline foot $(\mathrm{ft})$ & Length & \\
mile $(\mathrm{mi})$ & 0.3048 & meter $(\mathrm{m})$ \\
& 1.609 & kilometer $(\mathrm{km})$ \\
\hline foot per year $(\mathrm{ft} / \mathrm{yr})$ & Flow rate & \\
gallon per minute $(\mathrm{gal} / \mathrm{min})$ & 0.3048 & meter per year $(\mathrm{m} / \mathrm{yr})$ \\
gallon per day $(\mathrm{gal} / \mathrm{d})$ & 0.06309 & liter per second $(\mathrm{L} / \mathrm{s})$ \\
million gallons per day $(\mathrm{Mgal} / \mathrm{d})$ & 0.003785 & cubic meter per day $\left(\mathrm{m}^{3} / \mathrm{d}\right)$ \\
\hline
\end{tabular}

Vertical coordinate information is referenced to the National Geodetic Vertical Datum of 1929 (NGVD of 1929).

Horizontal coordinate information is referenced to the North American Datum of 1983 (NAD 1983).

Altitude as used in this report, refers to distance above the vertical datum. 


\title{
Water Levels in Aquifers in the Nacatoch Sand of Southwestern and Northeastern Arkansas and the Tokio Formation of Southwestern Arkansas, Spring 2008
}

\author{
By T.P. Schrader and Joshua M. Blackstock
}

\section{Abstract}

The Nacatoch Sand and Tokio Formation aquifers in southwestern Arkansas and the Nacatoch Sand in northeastern Arkansas are sources of water for industrial, public supply, domestic, and agricultural uses. Potentiometric-surface maps were constructed from water-level measurements made in 61 wells completed in the Nacatoch Sand and in 50 wells completed in the Tokio Formation during spring 2008. Aquifers in the Nacatoch Sand and Tokio Formation are hereafter referred to as the Nacatoch aquifer and the Tokio aquifer, respectively.

The direction of groundwater flow in the Nacatoch aquifer in northeastern Arkansas generally is towards the southeast. A potentiometric high is located along the north and northwestern boundaries of the area.

The direction of groundwater flow in the Nacatoch aquifer in southwestern Arkansas is towards the south-southeast in Little River, Miller, and Hempstead Counties and to the east-southeast in Nevada and Clark Counties. A potentiometric high is located within the outcrop area in north-central Hempstead County. A cone of depression exists in the Nacatoch aquifer at Hope in southeastern Hempstead County.

The direction of groundwater flow in the Tokio aquifer in southwestern Arkansas generally is towards the south or southeast. A potentiometric high is located within the outcrop area. Artesian conditions exist in southeastern Pike, northeastern Hempstead, and northwestern Nevada Counties. One apparent cone of depression might exist northwest of Hope in Hempstead County.

In northeastern Arkansas, groundwater withdrawals from the Nacatoch aquifer increased by 480 percent from 1965 to 2005. In southwestern Arkansas, withdrawals from the Nacatoch aquifer and Tokio aquifer increased by 125 percent and 201 percent, respectively, from 1965 to 1980 and decreased by 93 percent and 80 percent, respectively, from 1980 to 2000. Withdrawals from Nacatoch aquifer and Tokio aquifer increased by 690 percent and 291 percent, respectively, from 2000 to 2005 . Long-term hydrographs were prepared for 10 wells in the study areas. Changes in water levels in some wells may be associated with changes in withdrawals from the respective aquifers.

\section{Introduction}

Groundwater is a renewable resource important for economic growth and quality of life. Aquifers in the Nacatoch Sand and Tokio Formation in southwestern Arkansas and the Nacatoch Sand in northeastern Arkansas are sources of water for industrial, public supply, domestic, and agricultural uses. Monitoring of groundwater levels and withdrawals provides information to effectively plan and manage the resource. A study was conducted by the U.S. Geological Survey in cooperation with the Arkansas Natural Resources Commission and the Arkansas Geological Survey to provide potentiometricsurface maps and water-level hydrographs associated with aquifers in the Nacatoch Sand and Tokio Formation (hereafter referred to as the Nacatoch aquifer and Tokio aquifer, respectively) in southwestern Arkansas and the Nacatoch aquifer in northeastern Arkansas.

The study areas comprise parts of 10 counties in two areas of northeastern and southwestern Arkansas. The northeastern area includes most of Clay and Greene Counties in the Mississippi Alluvial Plain physiographic province (fig. 1). This area is bounded on the north and east by the Missouri State line and on the west by the western extent of the Nacatoch aquifer. The southern boundary of this area was defined by the southern extent of water withdrawals from wells screened in the Nacatoch aquifer. The southwestern area includes parts of eight counties (Clark, Hempstead, Howard, Little River, Miller, Nevada, Pike, and Sevier) in the West Gulf Coastal Plain physiographic province (fig. 1). This area is bounded on the north approximately by the Fall Line separating the Interior Highlands from the Coastal Plain, on the west by the extent of use and the availability of wells, and on the east by the eastern borders of Clark and Nevada Counties. The southwestern area was limited to the occurrence of freshwater; the southern boundary of the area is defined by a freshwater/ 


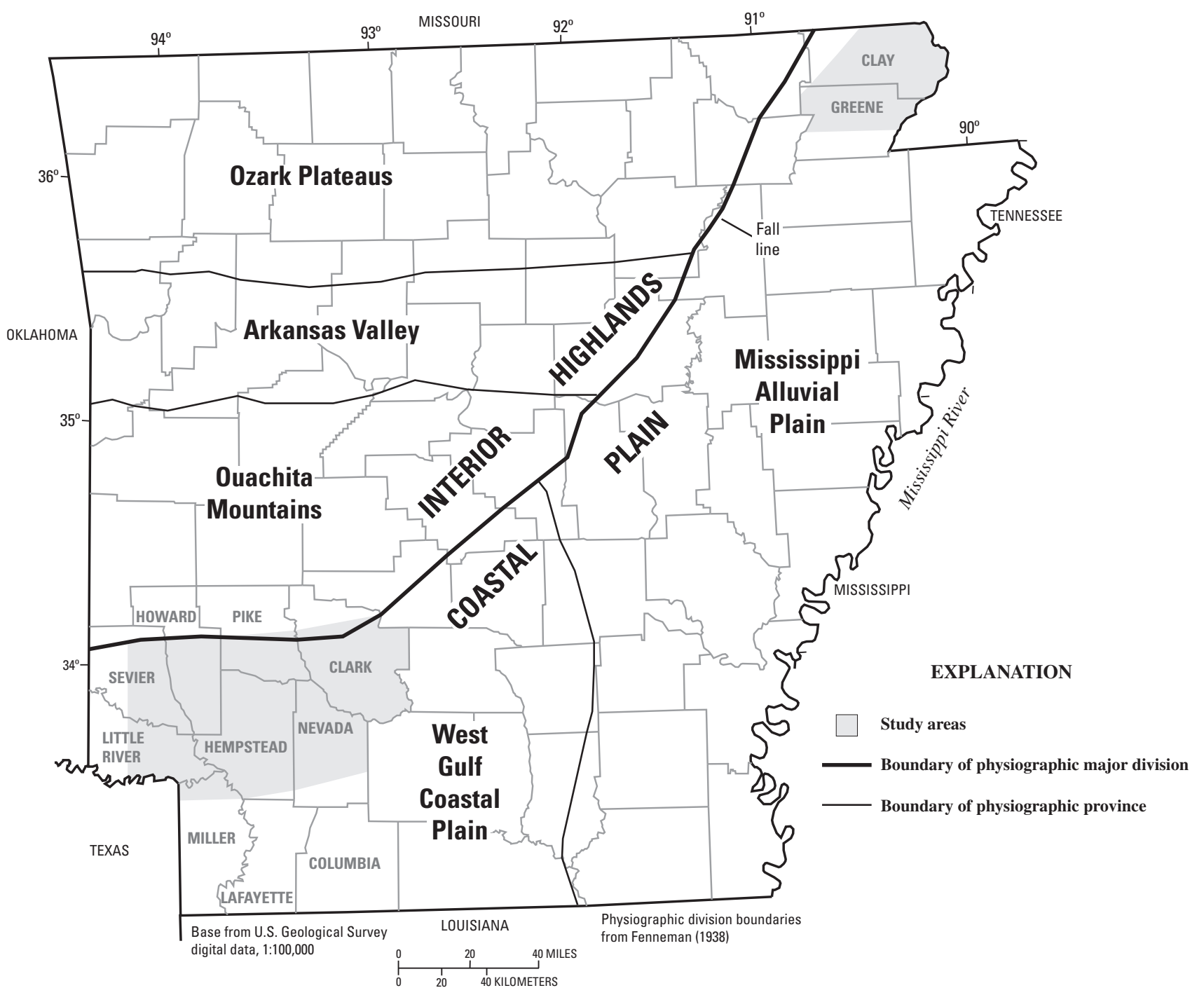

Figure 1. Location of study areas.

saltwater interface. To the south, the groundwater is considered saline (more than 1,000 milligrams per liter of dissolved solids) and is not suitable for most uses (Boswell and others, 1965; Petersen and others, 1985).

This report presents the results of water-level measurements made in 61 wells completed in the Nacatoch aquifer and in 50 wells completed in the Tokio aquifer during spring 2008. These measurements were used to construct potentiometricsurface maps. All water-level data are stored in the U.S. Geological Survey's Ground-Water Site Inventory (GWSI) data storage system (http://waterdata.usgs.gov). Long-term water-level hydrographs were prepared for selected wells. Withdrawal data for the aquifers in each county collected by the U.S. Geological Survey from 1965 to 2005 were related to these hydrographs.
The Tokio Formation is stratigraphically below the Nacatoch Sand and separated from it by five stratigraphic units, listed here in descending stratigraphic order: Saratoga Chalk, Marlbrook Marl, Annona Chalk, Ozan Formation, and Brownstown Marl. The Saratoga Chalk, Marlbrook Marl, and Annona Chalk are nonwater bearing, and the five-unit section can obtain a thickness of 900 feet (ft) (Petersen and others, 1985). These five units rarely are used as water sources and are not discussed in this report.

As a well is pumped, water levels decline, forming a cone of depression. Pumping rates that exceed recharge rates for an extended period of time will cause cones of depression to enlarge. Local cones of depression can intersect and coalesce, causing a regional decrease in water levels within the aquifer. Variations in climatic conditions and resulting recharge rates can result in the natural rise or decline of water levels and may account for changes shown by long-term hydrographs. 


\section{Methods}

Personnel from the U.S. Geological Survey (USGS) collected water-level measurements during spring 2008 from wells screened in the Nacatoch aquifer or Tokio aquifer. Measurements by USGS personnel were made with steel or electric tapes graduated in hundredths of a foot. The steel and electric tapes were calibrated during January 2008 prior to collecting measurements from wells. Calibration of steel and electric tapes was performed by comparing the field steel or electric tape to a standardized steel tape used only for calibration.

Well locations were measured using Global Positioning System receivers to acquire the horizontal coordinate information (latitude and longitude) based on the North American Datum of 1983. Land-surface altitude, feet above National Geodetic Vertical Datum of 1929 (NGVD of 1929), was determined for each well by superposition of the wells latitude and longitude on a topographic map and is accurate to about one-half the topographic contour interval of 5 or $10 \mathrm{ft}$. Herein, all water-level and land-surface altitudes are referenced to NGVD of 1929.

The well-numbering system used in this report is based upon the location of the wells according to the Federal land survey used in Arkansas. The component parts of a well number are the township number; the range number; the section number; three letters that indicate, respectively, the quarter section, the quarter-quarter section, and the quarter-quarterquarter section in which the well is located; and a sequence number of the well in the quarter-quarter-quarter section. The letters are assigned counterclockwise, beginning with " $\mathrm{A}$ " in the northeast quarter or quarter-quarter or quarter-quarterquarter section in which the well is located. For example, well 01S03W04BBD16 (fig. 2) is located in Township 1 South, Range 3 West, and in the southeast quarter of the northwest quarter of the northwest quarter of section 4 . This well is the 16th well in this quarter-quarter-quarter section of section 4 from which data were collected.

\section{Nacatoch Sand}

\section{Hydrogeologic Setting}

The Nacatoch Sand of Late Cretaceous age is underlain by the Saratoga Chalk and overlain by the Arkadelphia Marl. In the northeastern area, the Nacatoch Sand subcrops beneath Quaternary alluvial and terrace deposits along the western boundary. The top of the Nacatoch Sand has an altitude of about 50 to $100 \mathrm{ft}$ above NGVD of 1929 along the western boundary, dips toward the southeast, and descends to about 1,200 ft below NGVD of 1929 at the Mississippi River. This unit is about $100 \mathrm{ft}$ thick near the subcrop and attains a

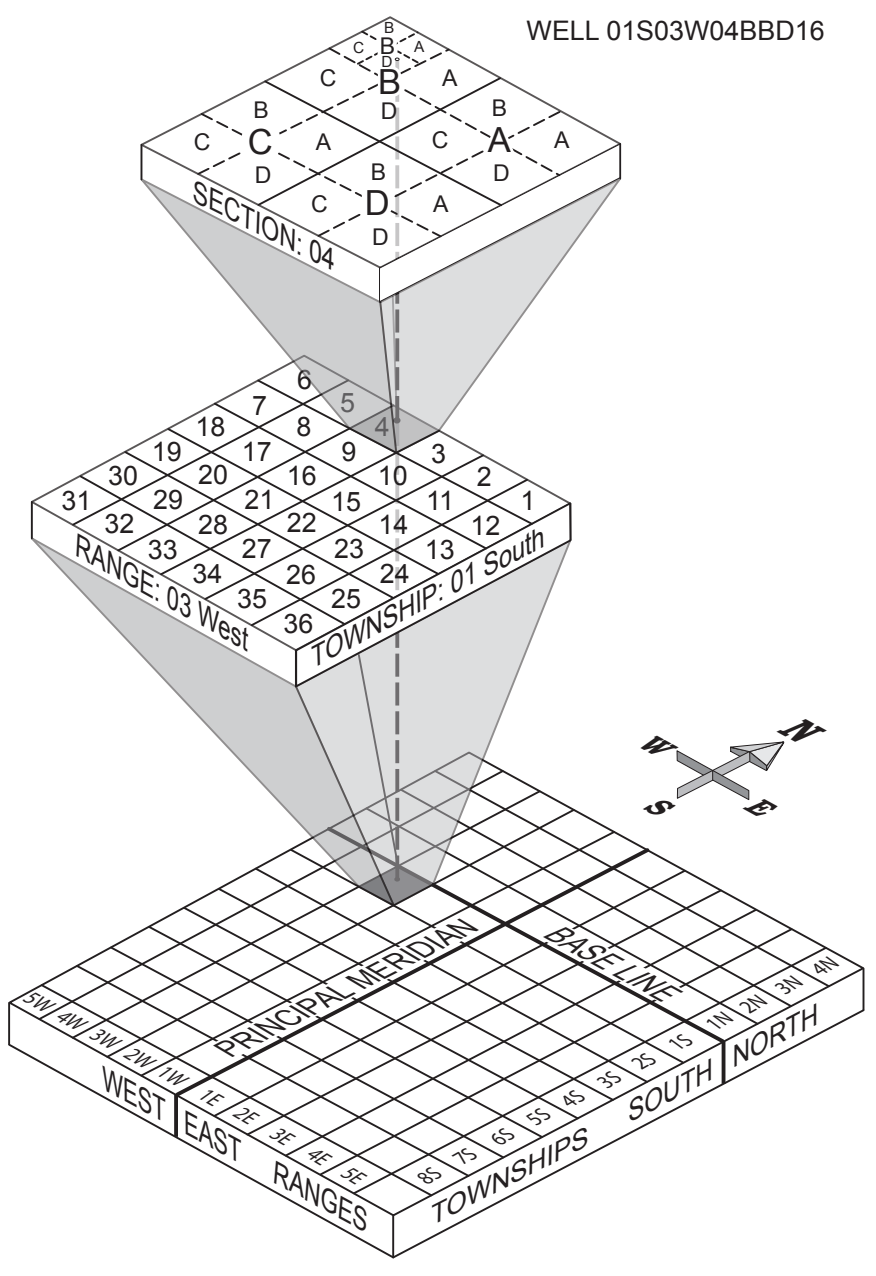

Figure 2. Well-numbering system.

maximum thickness of about $600 \mathrm{ft}$ downdip (Petersen and others, 1985).

The Nacatoch Sand in the northeastern area consists of interbedded clay, limestone, and fine sand in the lower part, grading upward to loose fine quartz sand in the upper part (Petersen and others, 1985). The Nacatoch aquifer receives recharge from precipitation through the overlying alluvium and terrace deposits in western Clay and Greene Counties.

In the southwestern area, the Nacatoch Sand outcrops in a belt 3 to 8 miles (mi) wide extending from central Clark County southwestward to western Hempstead County. The belt continues westward as a subcrop below Quaternary alluvial and terrace deposits across Little River County (Boswell and others, 1965). The top of the Nacatoch Sand has an altitude of about $300 \mathrm{ft}$ above NGVD of 1929 in the outcrop, dips towards the southeast, and descends to about $800 \mathrm{ft}$ below NGVD of 1929 at the southern boundary of the area. The Nacatoch Sand is about $100 \mathrm{ft}$ thick near the outcrop and attains a maximum thickness of $600 \mathrm{ft}$ (Petersen and others, 1985). 
The Nacatoch Sand in the southwestern area consists of three distinct units. The upper unit is composed of unconsolidated, gray, fine-grained quartz sand that commonly is crossbedded. Locally, the sand is massive and contains a few hard lenses and beds of fossiliferous sandy limestone. This upper sand unit is the main water-bearing unit of the Nacatoch Sand. The middle unit consists of a dark-green sand that contains coarse grains of glauconite and weathers to lighter shades of green. This unit generally is fossiliferous where it is glauconitic. The lower unit consists of interbedded gray clay, sandy clay and marl, dark clay-rich fine-grained sand, and hard irregular concretionary beds (Counts and others, 1955; Plebuch and Hines, 1969).

In the southwestern area, the Nacatoch aquifer receives recharge from precipitation in its outcrop areas in Clark, Nevada, and Hempstead Counties and through the overlying alluvium and terrace deposits in Little River County and in northeastern Texas. The Nacatoch aquifer is used in northeastern Greene County, Clay County, southern Clark County, northwestern Nevada County, central Hempstead County, northern Miller County, and southeastern Little River County. Flowing artesian wells produce yields of 1 or 2 gallons per minute (gal/min) in the lowest stream valleys in Clark and Nevada Counties. Wells in Hempstead County and western Nevada County produce yields of 150 to $300 \mathrm{gal} / \mathrm{min}$. In the southwestern area, downdip about 2 to 20 mi southeast of the outcrop area, groundwater generally is excessively saline for most uses. Well yields in Miller County, eastern Nevada County, and Clark County generally are small, and the water may contain considerable chloride (Counts and others, 1955). Aquifer tests of wells completed in the Nacatoch aquifer at Hope and Prescott show a transmissivity of 3,600 gallons per day per foot (gal/d/ft) (Ludwig, 1972).

\section{Water Use}

Total withdrawals from the Nacatoch aquifer in the northeastern area were 0.25 million gallons per day (Mgal/d) in 1965 and increased to $2.21 \mathrm{Mgal} / \mathrm{d}$ in 1990, an increase of 784 percent during the 25 -year period (fig. 3 ). The majority of these withdrawals occurred in Clay County and were $0.25 \mathrm{Mgal} / \mathrm{d}$ in 1965 and increased to $1.98 \mathrm{Mgal} / \mathrm{d}$ in 1990, an increase of 692 percent. Withdrawals in Greene County were $0.00 \mathrm{Mgal} / \mathrm{d}$ in 1965 and increased to $0.23 \mathrm{Mgal} / \mathrm{d}$ in 1990 . The total amount of withdrawals in the northeastern area in 2005 was $1.45 \mathrm{Mgal} / \mathrm{d}$, a decrease of 34 percent from 1990. This trend is explained by the decrease in withdrawals from Clay County from $1.98 \mathrm{Mgal} / \mathrm{d}$ in 1990 to $0.97 \mathrm{Mgal} / \mathrm{d}$ in 2005. However, withdrawals have increased in Greene County from $0.23 \mathrm{Mgal} / \mathrm{d}$ in 1990 to $0.48 \mathrm{Mgal} / \mathrm{d}$ in 2005 , an increase of 200 percent. From 1965 to 2005, withdrawals from the Nacatoch aquifer increased by 480 percent. Withdrawals in Clay County have increased from $0.25 \mathrm{Mgal} / \mathrm{d}$ in 1965 to 0.97

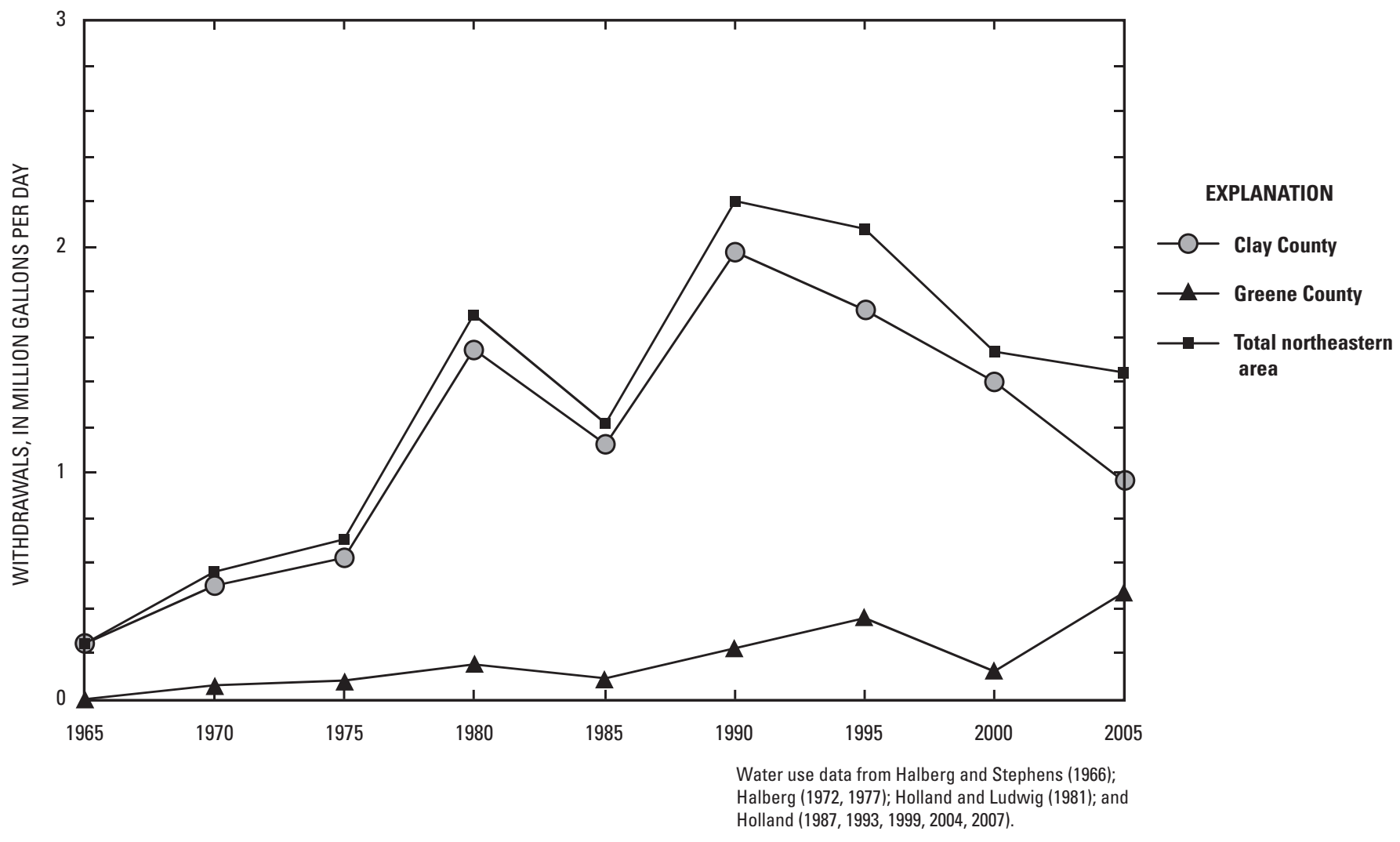

Figure 3. Withdrawals for the Nacatoch aquifer for the northeastern area in Arkansas. 
$\mathrm{Mgal} / \mathrm{d}$ in 2005, an increase of 288 percent. Withdrawals in Greene County have increased from $0.06 \mathrm{Mgal} / \mathrm{d}$ in 1970 to $0.48 \mathrm{Mgal} / \mathrm{d}$ in 2005, an increase of 700 percent (Halberg and Stephens, 1966; Holland and Ludwig, 1981; Holland, 1987, 1993, 1999, 2004, 2007).

Withdrawals from the Nacatoch aquifer in the southwestern area were $2.11 \mathrm{Mgal} / \mathrm{d}$ in 1965 and increased by 125 percent to $4.75 \mathrm{Mgal} / \mathrm{d}$ in 1980 (fig. 4). During this period, the largest withdrawals occurred in Hempstead County where withdrawals increased from $1.12 \mathrm{Mgal} / \mathrm{d}$ in 1965 to 1.98 $\mathrm{Mgal} / \mathrm{d}$ in 1980, an increase of 77 percent. Withdrawals in Clark County increased from $0.44 \mathrm{Mgal} / \mathrm{d}$ in 1965 to 1.73 $\mathrm{Mgal} / \mathrm{d}$ in 1980, an increase of 293 percent. Withdrawals in Howard, Little River, Miller, and Nevada County were 0.00 , $0.20,0.14$, and $0.21 \mathrm{Mgal} / \mathrm{d}$, respectively, in 1965. In 1980, Howard and Nevada County withdrawals increased to 0.24 and $0.68 \mathrm{Mgal} / \mathrm{d}$, respectively. However, withdrawals in Little River and Miller County decreased to $0.06 \mathrm{Mgal} / \mathrm{d}$. Withdrawals from the Nacatoch aquifer in this area were $0.32 \mathrm{Mgal} / \mathrm{d}$ in 2000, a decrease of 93 percent from 1980. In 2000, withdrawals in Clark, Hempstead, and Miller County decreased to 0.02, 0.27 , and $0.03 \mathrm{Mgal} / \mathrm{d}$, respectively. Withdrawals in Howard, Little River, and Nevada County decreased to $0.00 \mathrm{Mgal} / \mathrm{d}$ in 2000. The sharp decrease in withdrawal rates is explained by public water supplies in the southwestern area converting to a surface-water source and relying less on groundwater sources (Halberg and Stephens, 1966; Holland and Ludwig, 1981; Holland, 1987, 1993, 1999, 2004). However, in 2005, groundwater withdrawals increased to $2.53 \mathrm{Mgal} / \mathrm{d}$. Withdrawals increased in Clark, Hempstead, and Nevada County. Withdrawals in Clark and Nevada County increased to 0.43 and $0.18 \mathrm{Mgal} / \mathrm{d}$, respectively, in 2005. In Hempstead County, withdrawals increased from 0.27 in 2000 to $1.92 \mathrm{Mgal} / \mathrm{d}$ in 2005, an increase of 711 percent (Holland, 2007).

\section{Potentiometric Surface}

Water-level measurements in 61 wells during spring 2008 were used to construct potentiometric-surface maps for the Nacatoch aquifer (figs. 5 and 6; table 1). The potentiometric surface was mapped by calculating the altitude of the water levels (table 1) and is represented by contour lines of equal water-level altitude value. The general direction of groundwater flow is perpendicular to the contour lines in the direction of downward hydraulic gradient.

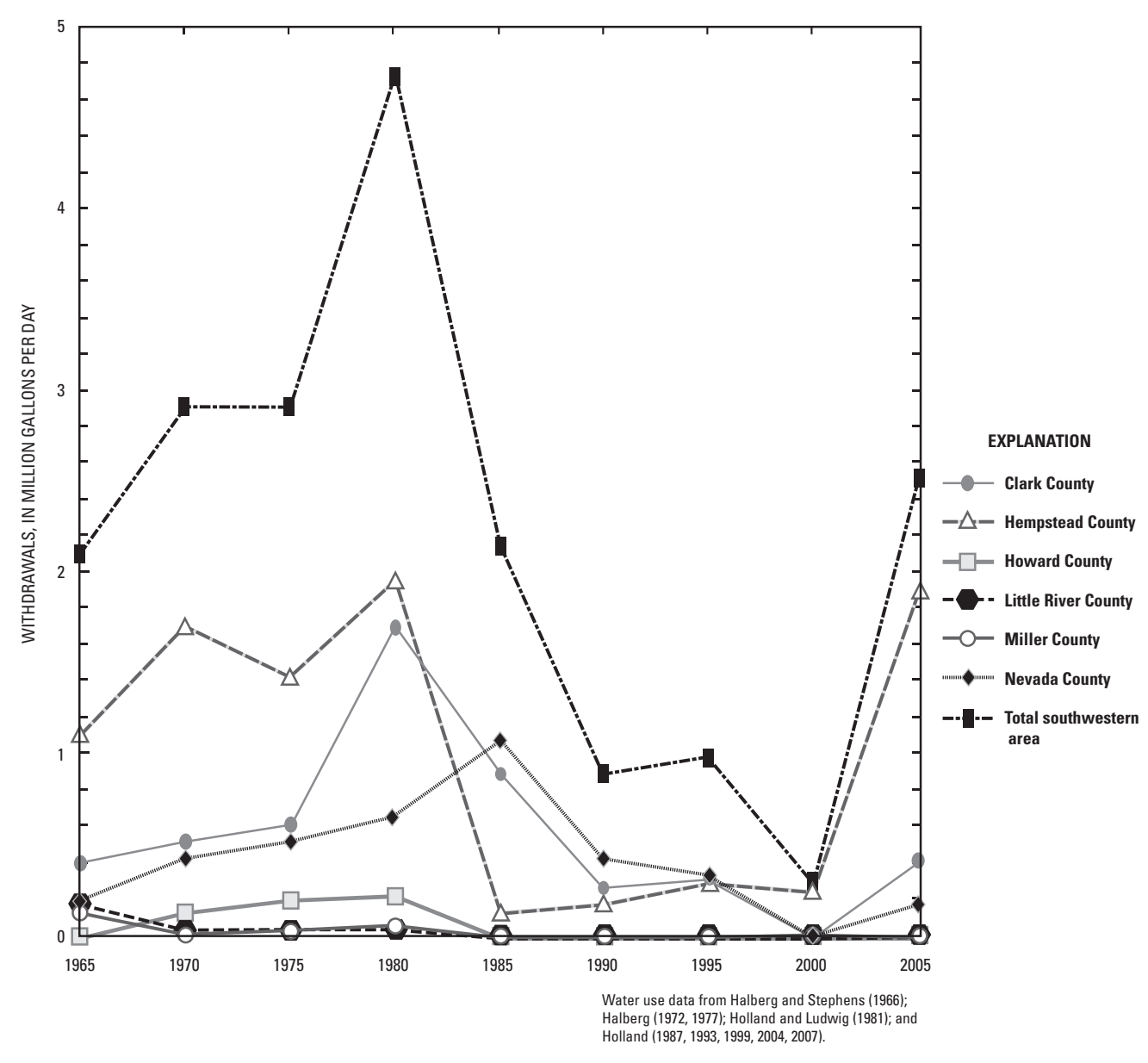

Figure 4. Withdrawals for the Nacatoch aquifer for the southwestern area in Arkansas. 


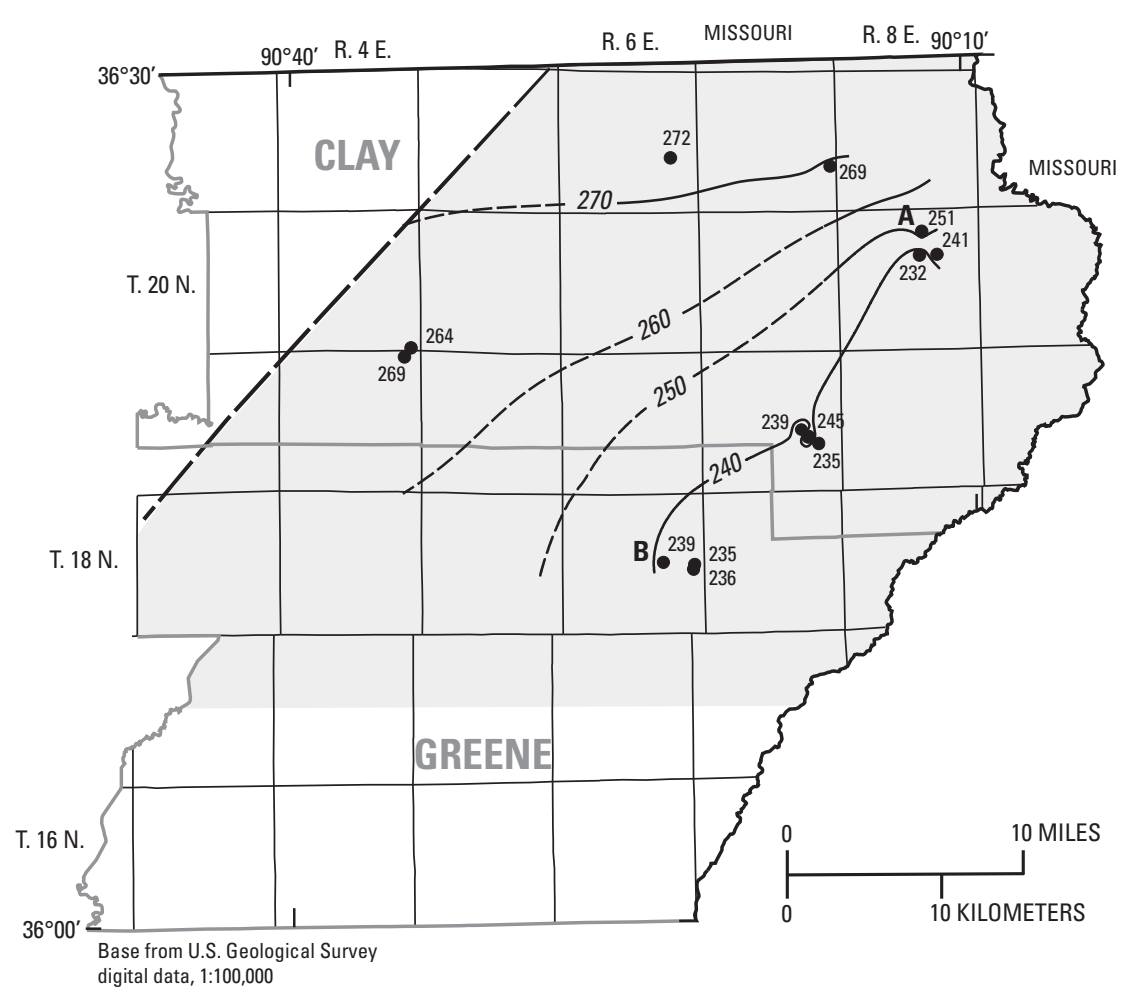

EXPLANATION

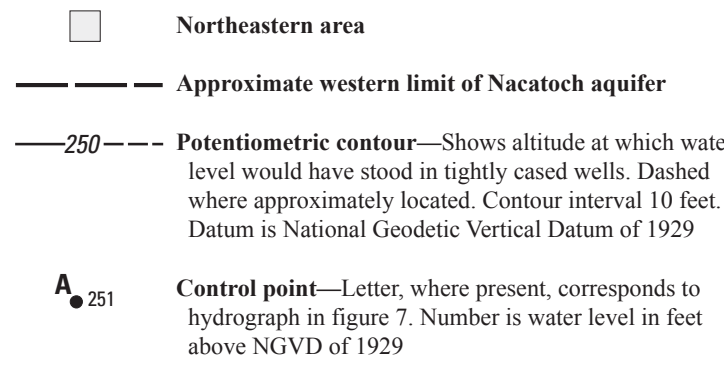

Figure 5. Potentiometric surface of the Nacatoch aquifer, northeastern Arkansas, spring 2008. 


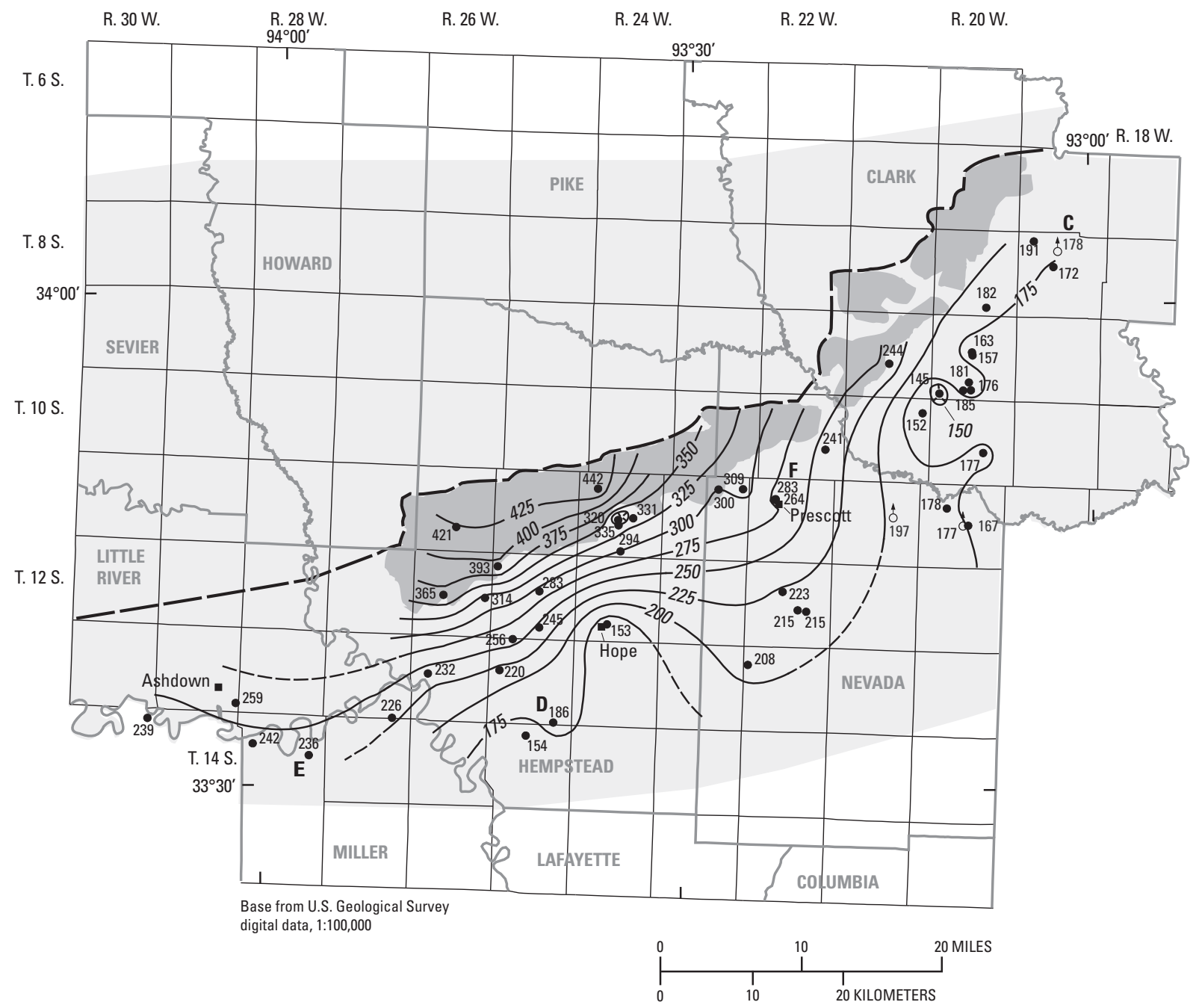

\section{EXPLANATION}

Southwestern area

Outcrop of Nacatoch Sand

Approximate northern limit of Nacatoch aquifer
$250--\begin{gathered}\text { Potentiometric contour-Shows altitude at which water level would } \\ \text { have stood in tightly cased wells. Dashed where approximately located }\end{gathered}$ have stood in tightly cased wells. Dashed where approximately located.

Hachures indicate depression. Contour interval 25 feet. Datum is

National Geodetic Vertical Datum of 1929

D. 186

Control point-Letter, where present, corresponds to hydrograph in

figure 7. Number is water level in feet above NGVD of 1929

$\dot{t}^{197}$

Flowing artesian well-Number is water level in feet above NGVD of 1929

Figure 6. Potentiometric surface of the Nacatoch aquifer, southwestern Arkansas, spring 2008. 
8 Water Levels in Aquifers in the Nacatoch Sand and the Tokio Formation, Spring 2008

Table 1. Water-level data collected during spring 2008 from wells completed in the Nacatoch Sand.

[NGVD of 1929, National Geodetic Vertical Datum of 1929; Horizontal datum is North American Datum of 1983]

\begin{tabular}{|c|c|c|c|c|c|c|}
\hline Station Name & $\begin{array}{l}\text { Latitude } \\
\text { (degrees, } \\
\text { minutes, } \\
\text { seconds) }\end{array}$ & $\begin{array}{l}\text { Longitude } \\
\text { (degrees, } \\
\text { minutes, } \\
\text { seconds) }\end{array}$ & $\begin{array}{c}\text { Water-level } \\
\text { altitude } \\
\text { (feet above } \\
\text { NGVD of 1929) }\end{array}$ & $\begin{array}{l}\text { Depth to water } \\
\text { (feet below } \\
\text { land surface) }\end{array}$ & $\begin{array}{c}\text { Land-surface } \\
\text { datum } \\
\text { (feet above } \\
\text { NGVD of 1929) }\end{array}$ & $\begin{array}{c}\text { Date of } \\
\text { measurement }\end{array}$ \\
\hline \multicolumn{7}{|c|}{ Clark } \\
\hline 08S19W06DCB1 & 340359 & 930433 & 191 & 78.98 & 270 & $2 / 28 / 2008$ \\
\hline 08S19W09ACC1 & 340323 & 930228 & 178 & -0.85 & 177 & $2 / 28 / 2008$ \\
\hline 08S19W16CAB1 & 340226 & 930247 & 172 & 0.78 & 173 & $2 / 28 / 2008$ \\
\hline 08S20W34DAB1 & 335954 & 930744 & 182 & 18.47 & 200 & $2 / 28 / 2008$ \\
\hline 09S20W16DBD1 & 335708 & 930847 & 163 & 77.83 & 241 & $2 / 28 / 2008$ \\
\hline 09S20W16DDC1 & 335657 & 930845 & 157 & 75.93 & 233 & $2 / 28 / 2008$ \\
\hline 09S20W28DCB1 & 335516 & 930901 & 185 & 16.93 & 202 & $2 / 28 / 2008$ \\
\hline 09S20W31CAD1 & 335435 & 931111 & 145 & 114.39 & 259 & $2 / 28 / 2008$ \\
\hline 09S20W33ABD1 & 335447 & 930852 & 176 & 33.33 & 209 & $2 / 28 / 2008$ \\
\hline 09S20W33BCD2 & 335446 & 930926 & 181 & 26.22 & 207 & $2 / 28 / 2008$ \\
\hline 09S21W21DAD1 & 335625 & 931453 & 244 & 100.76 & 345 & $2 / 28 / 2008$ \\
\hline 10S20W22DCB1 & 335054 & 930757 & 177 & 83.18 & 260 & $2 / 28 / 2008$ \\
\hline 10S21W12BAB1 & 335321 & 931225 & 152 & 69.26 & 221 & $2 / 28 / 2008$ \\
\hline \multicolumn{7}{|c|}{ Clay } \\
\hline 19N04E01BDB1 & 361910 & 903560 & 269 & 11.33 & 280 & $3 / 03 / 2008$ \\
\hline 19N07E23BAC1 & 361602 & 901748 & 239 & 82.64 & 322 & $303 / 2008$ \\
\hline 19N07E23DBC1 & 361549 & 901730 & 245 & 37.68 & 283 & $3 / 03 / 2008$ \\
\hline 19N07E26AAA1 & 361532 & 901703 & 235 & 41.18 & 276 & $3 / 03 / 2008$ \\
\hline 20N04E36DCC1 & 361929 & 903542 & 264 & 15.24 & 279 & $3 / 03 / 2008$ \\
\hline 20N08E10ABC1 & 362313 & 901202 & 251 & 88.97 & 340 & $3 / 03 / 2008$ \\
\hline 20N08E14BAB2 & 362227 & 901120 & 241 & 44.63 & 286 & $3 / 03 / 2008$ \\
\hline 20N08E15BAA1 & 362224 & 901208 & 232 & 148.86 & 381 & $3 / 03 / 2008$ \\
\hline 21N06E23DAC1 & 362619 & 902329 & 272 & 28.02 & 300 & $3 / 03 / 2008$ \\
\hline 21N07E25AAC1 & 362550 & 901607 & 269 & 72.77 & 342 & $3 / 03 / 2008$ \\
\hline \multicolumn{7}{|c|}{ Greene } \\
\hline 18N06E14CCD1 & 361115 & 902420 & 239 & 48.12 & 287 & $3 / 04 / 2008$ \\
\hline 18N06E24ABB2 & 361112 & 902256 & 235 & 34.69 & 270 & $3 / 04 / 2008$ \\
\hline 18N06E24BDA1 & 361058 & 902300 & 236 & 39.84 & 276 & $3 / 04 / 2008$ \\
\hline \multicolumn{7}{|c|}{ Hempstead } \\
\hline 11S24W08BDB1 & 334837 & 933619 & 442 & 28.18 & 470 & $2 / 26 / 2008$ \\
\hline 11S24W21ADD1 & 334641 & 933449 & 320 & 50.29 & 370 & $2 / 26 / 2008$ \\
\hline 11S24W21DDD1 & 334621 & 933447 & 335 & 35.97 & 371 & $2 / 26 / 2008$ \\
\hline 11S24W22ADD1 & 334647 & 933343 & 331 & 34.13 & 365 & $2 / 26 / 2008$ \\
\hline 11S24W34CBC1 & 334444 & 933438 & 294 & 26.28 & 320 & $2 / 26 / 2008$ \\
\hline 11S26W27BDD1 & 334611 & 934645 & 421 & 9.16 & 430 & $2 / 25 / 2008$ \\
\hline 12S24W28CDC1 & 334012 & 933536 & 153 & 200.18 & 353 & $2 / 22 / 2008$ \\
\hline 12S25W07ABB1 & 334346 & 934340 & 393 & 42.14 & 435 & $2 / 25 / 2008$ \\
\hline 12S25W15DBC1 & 334214 & 934036 & 283 & 28.17 & 311 & $2 / 22 / 2008$ \\
\hline
\end{tabular}


Table 1. Water-level data collected during spring 2008 from wells completed in the Nacatoch Sand.-Continued

[NGVD of 1929, National Geodetic Vertical Datum of 1929; Horizontal datum is North American Datum of 1983]

\begin{tabular}{|c|c|c|c|c|c|c|}
\hline Station Name & $\begin{array}{l}\text { Latitude } \\
\text { (degrees, } \\
\text { minutes, } \\
\text { seconds) }\end{array}$ & $\begin{array}{l}\text { Longitude } \\
\text { (degrees, } \\
\text { minutes, } \\
\text { seconds) }\end{array}$ & $\begin{array}{c}\text { Water-level } \\
\text { altitude } \\
\text { (feet above } \\
\text { NGVD of 1929) }\end{array}$ & $\begin{array}{l}\text { Depth to water } \\
\text { (feet below } \\
\text { land surface) }\end{array}$ & $\begin{array}{c}\text { Land-surface } \\
\text { datum } \\
\text { (feet above } \\
\text { NGVD of 1929) }\end{array}$ & $\begin{array}{c}\text { Date of } \\
\text { measurement }\end{array}$ \\
\hline \multicolumn{7}{|c|}{ Hempstead-Continued } \\
\hline 12S25W34BAC1 & 334002 & 934055 & 245 & 74.80 & 320 & $2 / 26 / 2008$ \\
\hline 12S26W21AAC1 & 334158 & 934739 & 365 & 32.66 & 398 & $2 / 21 / 2008$ \\
\hline 12S26W24ABC1 & 334159 & 934438 & 314 & 0.72 & 315 & $2 / 21 / 2008$ \\
\hline 13S25W05ABD1 & 333915 & 934232 & 256 & 26.23 & 282 & $2 / 22 / 2008$ \\
\hline 13S25W18AAB1 & 333740 & 934332 & 220 & 62.99 & 283 & $2 / 22 / 2008$ \\
\hline 13S25W35DDC1 & 333406 & 933931 & 186 & 187.49 & 373 & $2 / 26 / 2008$ \\
\hline 13S26W17DDB1 & 333705 & 934845 & 232 & 58.57 & 291 & $2 / 21 / 2008$ \\
\hline 14S25W04DDD1 & 333317 & 934132 & 154 & 105.94 & 260 & $2 / 26 / 2008$ \\
\hline \multicolumn{7}{|c|}{ Little River } \\
\hline 13S28W31BCC1 & 333509 & 940251 & 259 & 51.81 & 311 & $2 / 19 / 2008$ \\
\hline 14S30W01DAA1 & 333426 & 940904 & 239 & 43.32 & 282 & $2 / 19 / 2008$ \\
\hline \multicolumn{7}{|c|}{ Miller } \\
\hline 14S27W02AAB1 & 333419 & 935121 & 226 & 29.23 & 255 & $2 / 20 / 2008$ \\
\hline 14S28W13CCB1 & 333158 & 935727 & 236 & 29.53 & 266 & $2 / 20 / 2008$ \\
\hline 14S28W17BBC1 & 333240 & 940134 & 242 & 28.42 & 270 & $2 / 20 / 2008$ \\
\hline \multicolumn{7}{|c|}{ Nevada } \\
\hline 10S22W23DCB1 & 335105 & 931935 & 241 & 0.66 & 242 & $2 / 27 / 2008$ \\
\hline 11S20W08DCD1 & 334727 & 931037 & 178 & 3.18 & 181 & $2 / 27 / 2008$ \\
\hline 11S20W15CDC1 & 334622 & 930905 & 167 & 8.12 & 175 & $2 / 27 / 2008$ \\
\hline 11S20W22AAA1 & 334624 & 930926 & 177 & -1.76 & 175 & $2 / 27 / 2008$ \\
\hline 11S21W14CAB1 & 334652 & 931434 & 197 & -1.20 & 196 & $2 / 27 / 2008$ \\
\hline 11S22W08DAC2 & 334760 & 932314 & 264 & 41.70 & 306 & $2 / 26 / 2008$ \\
\hline 11S22W08DDB4 & 334757 & 932314 & 283 & 22.92 & 306 & $2 / 26 / 2008$ \\
\hline 11S23W03DCD1 & 334840 & 932726 & 300 & 85.28 & 385 & $2 / 26 / 2008$ \\
\hline 11S23W12ABB1 & 334837 & 932541 & 309 & 72.40 & 381 & $2 / 26 / 2008$ \\
\hline 12S22W09CDD1 & 334230 & 932250 & 223 & 6.37 & 229 & $2 / 27 / 2008$ \\
\hline 12S22W22ACD1 & 334108 & 932135 & 215 & 126.93 & 342 & $2 / 27 / 2008$ \\
\hline $12 \mathrm{~S} 22 \mathrm{~W} 23 \mathrm{CBA} 1$ & 334102 & 932057 & 215 & 114.00 & 329 & $2 / 27 / 2008$ \\
\hline 13S22W07BDC1 & 333744 & 932514 & 208 & 135.48 & 343 & $2 / 27 / 2008$ \\
\hline
\end{tabular}


In the southwestern area, the direction of groundwater flow in the Nacatoch aquifer is generally towards the southsoutheast in Little River, Miller, and Hempstead Counties and to the east-southeast in Nevada and Clark Counties (fig. 6). This direction of flow may be affected by the increase in clay content in the downdip direction (Boswell and others, 1965). The highest water-level altitude measured was $442 \mathrm{ft}$ in the outcrop area of north-central Hempstead County. The lowest water-level altitude measured was about $145 \mathrm{ft}$ in Clark County.

Three depressions exist in the southwestern area. The largest depression exists at Hope in Hempstead County (fig. 6). Historical water levels indicate a decline of $40 \mathrm{ft}$ from an altitude of $185 \mathrm{ft}$ in 1942 to $145 \mathrm{ft}$ in 1969 (Ludwig, 1972). The water-level altitude in January 2002 was $119 \mathrm{ft}$ (Schrader and Scheiderer, 2004). This depression alters local groundwater-flow directions from the regional direction, with groundwater flowing towards Hope from the west, north, and northeast directions. A comparison with the 2002 potentiometric-surface maps (Schrader and Scheiderer, 2004) for the Nacatoch aquifer exhibits a substantial rise in water level at Hope from 119 $\mathrm{ft}$ to $153 \mathrm{ft}$ in 2000. Small depressions exist in southern Clark County and northeastern Hempstead County. The water level in the depression in southern Clark County has declined about $1 \mathrm{ft}$ from $146 \mathrm{ft}$ in 2005 to $145 \mathrm{ft}$ in 2008 . The water level in the depression in northeastern Hempstead County has declined $1 \mathrm{ft}$ from 321 in 2005 to $320 \mathrm{ft}$ in 2008 . The rest of the southwestern and northeastern areas have minor variations in water level when compared to the 2005 maps.

\section{Long-Term Water-Level Changes}

Hydrographs from wells completed in the Nacatoch aquifer with long-term (minimum of 20 years) water-level measurements were constructed (two in the northeastern area and four in the southwestern area). A minimum 20-year period was used to minimize the effect of short-term variations in climate and localized pumping rates on water levels in a single well.

Two long-term hydrographs are associated with two wells (sites A and B, fig. 7) located in the northeastern area (fig. 5). Water levels in both of these wells have an annual decline of about $1.2 \mathrm{ft} / \mathrm{yr}$. In Clay County, well 20N08E10ABC1 consistently showed declines in water level from 1965 to 1990. These declines may be associated with increased withdrawals in Clay County during this period from $0.25 \mathrm{Mgal} / \mathrm{d}$ in 1965 to $1.98 \mathrm{Mgal} / \mathrm{d}$ in 1990 . However, water levels since 1998 have been relatively stable, which may also be associated with withdrawals. Since 1990, withdrawals in Clay County have decreased from $1.98 \mathrm{Mgal} / \mathrm{d}$ in 1990 to $0.97 \mathrm{Mgal} / \mathrm{d}$ in 2005, a decrease of 51 percent (Halberg and Stephens, 1966; Holland, 1993, 2007; Schrader, 2007). In Greene County, water levels in well 18N06E14CCD1 show an overall decline from 1977 until 1990. Water levels have been relatively stable since then. Overall declines in both wells may be associated with withdrawals from the Nacatoch aquifer in the northeastern area from 1965 to 2005 with the majority of withdrawals occurring in Clay County (fig. 3). However, relatively stable water levels in Clay County from 1990 to 2005 may also be associated with decreased withdrawals.

Four wells with historical water-level measurements (sites C-F; fig. 7) are located in the southwestern area (fig. 6). One well is located in each of the following four counties: Clark, Hempstead, Miller, and Nevada Counties. Water-level rise and decline varied by county.

Water levels in well 08S19W09ACC1 (site C, figs. 6 and 7) declined from about $186 \mathrm{ft}$ above NGVD of 1929 in 1962 to about $178 \mathrm{ft}$ in 2008, an annual decline of about $0.2 \mathrm{ft} / \mathrm{yr}$. The consistent decline in water level does not reflect the changes associated with water use from the Nacatoch aquifer in Clark County.

Water levels in well 13S25W35DDC1 (site D, figs. 6 and 7) declined from $188 \mathrm{ft}$ in 1975 to $175 \mathrm{ft}$ in 1979 . Water use from the Nacatoch aquifer in Hempstead County increased from $1.44 \mathrm{Mgal} / \mathrm{d}$ in 1975 to $1.98 \mathrm{Mgal} / \mathrm{d}$ in 1980 (Halberg, 1977; Holland and Ludwig, 1981), an increase of 72 percent (fig. 4). Water use declined from $1.98 \mathrm{Mgal} / \mathrm{d}$ in 1980 to 0.15 $\mathrm{Mgal} / \mathrm{d}$ in 1985. From 1979 to 1999 , a general rise in water level was observed, but from 1999 to 2002, a sharp decrease in water level occurred. From 2005 to 2008, a small decrease in water level occurred. Water-use rates from the Nacatoch aquifer increased from $0.32 \mathrm{Mgal} / \mathrm{d}$ in 2000 to $2.53 \mathrm{Mgal} / \mathrm{d}$ in 2005, an increase of about 690 percent (Holland, 1987, 1999, 2004, 2007). These fluctuations in water level can be explained by corresponding changes in water use from the Nacatoch aquifer in Hempstead County.

Water levels in well 14S28W13CCB1 (site E, figs. 6 and 7) ranged from $248 \mathrm{ft}$ to $236 \mathrm{ft}$ from 1962 to 2008 . Withdrawals in Miller County were less than $0.10 \mathrm{Mgal} / \mathrm{d}$ from 1970 through 2005 (fig. 4). Water-level changes in this well cannot be attributed to a specific factor.

Water levels in well 11S22W08DAC2 (site F, figs. 6 and 7), increased from about $179 \mathrm{ft}$ in 1985 to about $267 \mathrm{ft}$ in 1990, an average rise of about $17.6 \mathrm{ft} / \mathrm{yr}$ in the 5-year period (Schrader, 2007). This increase in water levels occurred when the withdrawal rates from the Nacatoch aquifer in Nevada County decreased from $1.11 \mathrm{Mgal} / \mathrm{d}$ in 1985 to $0.44 \mathrm{Mgal} / \mathrm{d}$ in 1990 (Holland, 1987, 1993), a decrease of about 60 percent (fig. 4). Water levels declined $2 \mathrm{ft}$ from about 266 in 2005 to 264 in 2008.

Although water levels in these six wells located in the northeastern and southwestern areas may be associated with changes in water use, including localized withdrawals that are not apparent in the county totals, other factors also may affect water levels such as climatic variations or changes in leakage to and from overlying and underlying rock units. 


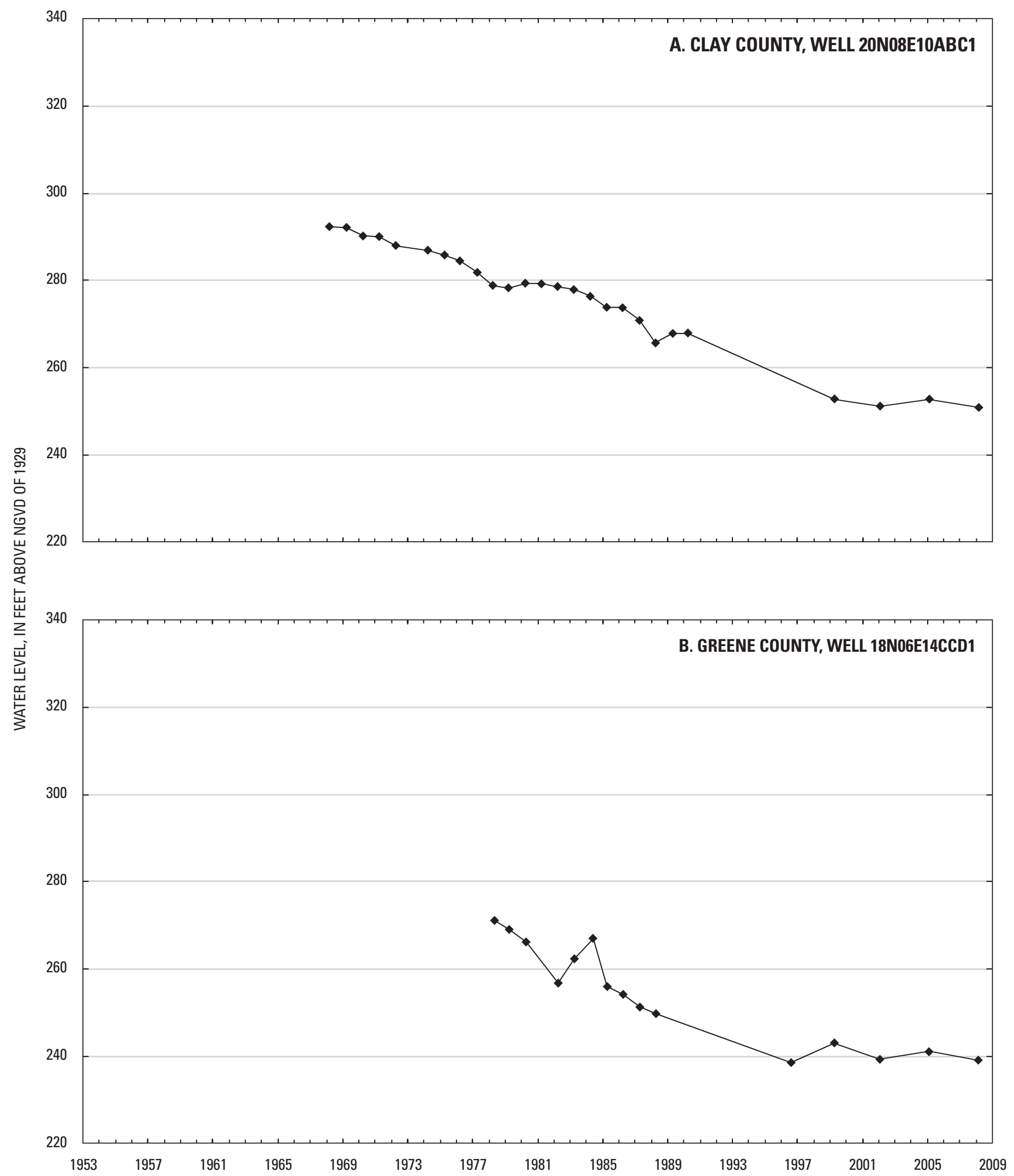

Figure 7. Water-level hydrographs for selected wells completed in the Nacatoch aquifer. 


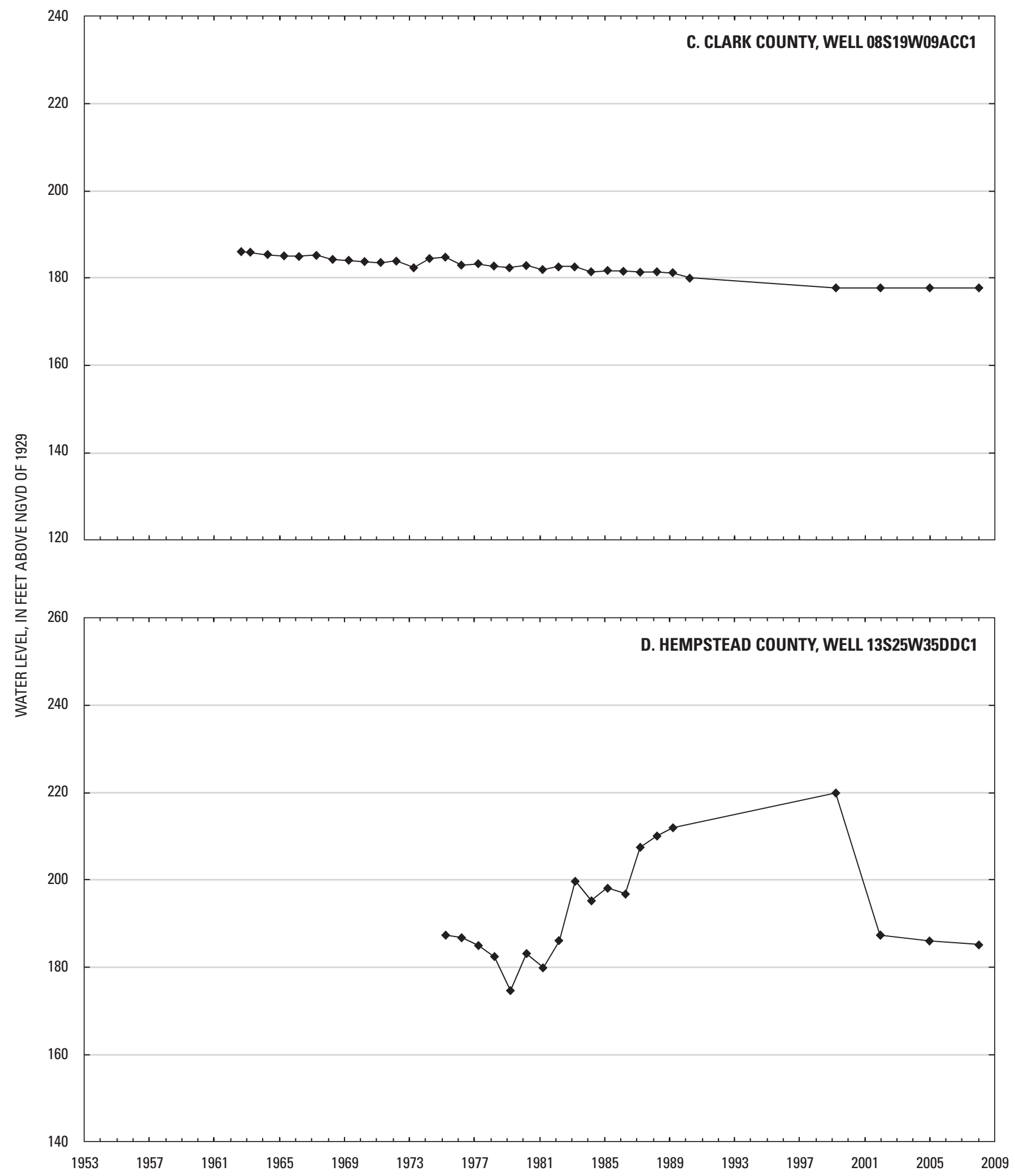

Figure 7. Water-level hydrographs for selected wells completed in the Nacatoch aquifer-—Continued 


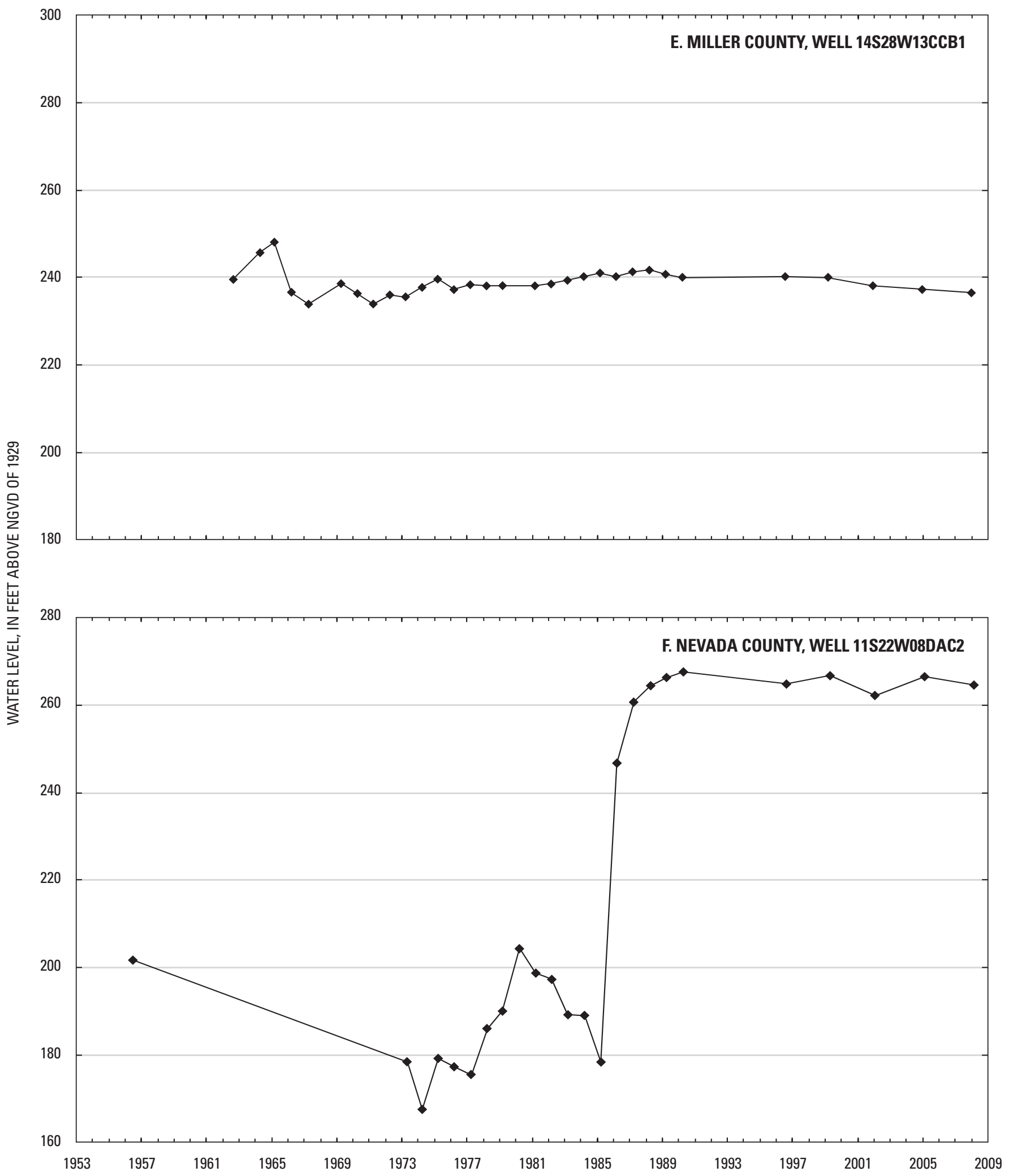

Figure 7. Water-level hydrographs for selected wells completed in the Nacatoch aquifer-Continued 


\section{Tokio Formation}

\section{Hydrogeologic Setting}

The Tokio Formation of Cretaceous age underlies the Brownstown Marl and overlies consolidated rocks of Mississippian and Pennsylvanian age in Clark and northeastern Nevada Counties (Plebuch and Hines, 1969); the Trinity Group of Early Cretaceous age in Pike, Nevada, Miller, and most of Hempstead Counties (Petersen and others, 1985); and the Woodbine Formation of Late Cretaceous age in Little River, Sevier, Howard, and northwestern Hempstead Counties (Boswell and others, 1965). The Tokio Formation outcrops in a southwest-to-northeast trending band from eastern Sevier County to west-central Clark County. The outcrop attains a maximum width of about $10 \mathrm{mi}$ in Howard County and extends approximately $8 \mathrm{mi}$ to the southwest into Sevier County. In this area, the Tokio Formation is overlain in several places by terrace deposits of Quaternary alluvium. The unit also outcrops in northwestern Little River County, west of the southwestern area. The unit ranges in thickness from about $50 \mathrm{ft}$ to more than $300 \mathrm{ft}$, dips towards the southeast, and is composed of discontinuous, interbedded gray clay and poorly sorted, crossbedded quartz sands, lignite, and a prevalent basal gravel (Counts and others, 1955; Boswell and others, 1965; Plebuch and Hines, 1969; Petersen and others; 1985). The Tokio Formation does not occur in the northeastern area.

The Tokio aquifer receives recharge from precipitation where it outcrops or is overlain by permeable alluvial and terrace deposits. Salinity increases downdip to the south-southeast. The Tokio aquifer yields freshwater to within a few miles north of Ashdown in Little River County (fig. 9) and becomes slightly to moderately saline downdip (southeast) from near Prescott to the fault zone trending across Nevada County (Petersen and others, 1985).

The Tokio aquifer yields potable water to wells in eastern Little River County, southeastern Sevier County, southern Howard and Pike Counties, western Clark County, northern and central Hempstead County, and northwestern Nevada County. Wells penetrating the Tokio aquifer range in depth from a few feet in the outcrop area to about 1,200 ft at Hope and Prescott (Ludwig, 1972). Wells in central Hempstead County yield up to $300 \mathrm{gal} / \mathrm{min}$. Wells flowing as much as 90 gal/min occur in the bottom-land areas adjacent to streams (Counts and others, 1955). Historic records indicate that water levels in the aquifer did not decline appreciably from 1950 to 1968, and that water levels had not been greatly affected by withdrawal of water at Hope and Prescott during this period (Ludwig, 1972).

\section{Water Use}

Water withdrawn from the Tokio aquifer increased by 201 percent from $2.0 \mathrm{Mgal} / \mathrm{d}$ in 1965 to $6.02 \mathrm{Mgal} / \mathrm{d}$ in 1980 (fig.
8). Water withdrawn from the Tokio aquifer was $1.17 \mathrm{Mgal} / \mathrm{d}$ in 2000, a decrease of 80 percent from 1980. Water withdrawn from the Tokio aquifer was $4.58 \mathrm{Mgal} / \mathrm{d}$ in 2005, an increase of 291 percent from 2000 (Halberg and Stephens, 1966; Holland and Ludwig, 1981; Holland, 1999, 2004, 2007).

Water-use data for the Tokio aquifer by county is variable, with increases or decreases occurring over 5- to 20-year periods. Water withdrawals in Hempstead County increased by 348 percent from $0.67 \mathrm{Mgal} / \mathrm{d}$ in 1965 to $3.0 \mathrm{Mgal} / \mathrm{d}$ in 1980 (fig. 8). Water withdrawn in Hempstead County was 0.76 $\mathrm{Mgal} / \mathrm{d}$ in 2000, a decrease of 75 percent from 1980. Water withdrawn increased to $2.10 \mathrm{Mgal} / \mathrm{d}$ in 2005, an increase of 213 percent from 2000. By county, Hempstead County was the largest user of water from the Tokio aquifer in 2005. In Sevier County, water withdrawals were $0.15 \mathrm{Mgal} / \mathrm{d}$ in 1965 , increasing to $1.15 \mathrm{Mgal} / \mathrm{d}$ in 1990, an increase of 667 percent from 1965. From 1990 to 2000, water withdrawn in Sevier County decreased to $0.30 \mathrm{Mgal} / \mathrm{d}$ in 2000 , a decrease of 74 percent from 1990. Water withdrawn in 2005 was $1.73 \mathrm{Mgal} / \mathrm{d}$, an increase of 477 percent from 2000. In Howard County, water withdrawals were $0.69 \mathrm{Mgal} / \mathrm{d}$ in 1965 , increasing to 1.11 $\mathrm{Mgal} / \mathrm{d}$ in 1980, an increase of 61 percent from 1965. Water withdrawals decreased to $0.14 \mathrm{Mgal} / \mathrm{d}$ in 1985 and to less than $0.1 \mathrm{Mgal} / \mathrm{d}$ in 1990, 1995, and 2000. In 2005, water withdrawals increased to $0.50 \mathrm{Mgal} / \mathrm{d}$ in Howard County. In Nevada County, water withdrawals were $0.37 \mathrm{Mgal} / \mathrm{d}$ in 1965 , increasing to $0.68 \mathrm{Mgal} / \mathrm{d}$ in 1980 , an increase of 84 percent from 1965. Water withdrawals decreased to less than $0.1 \mathrm{Mgal} / \mathrm{d}$ in 1990, 1995, 2000, and 2005. In Pike County, water withdrawals were $0.12 \mathrm{Mgal} / \mathrm{d}$ in 1965 , increasing to $0.82 \mathrm{Mgal} / \mathrm{d}$ in 1980, an increase of 583 percent from 1965. Water withdrawals decreased to less than $0.1 \mathrm{Mgal} / \mathrm{d}$ in 1990, 1995, 2000, and 2005. Water withdrawls in Clark, Little River, and Miller Counties were less than $0.1 \mathrm{Mgal} / \mathrm{d}$ from 1965 through 2005 (Halberg and Stephens, 1966; Holland and Ludwig, 1981; Holland, 1999, 2004, 2007).

\section{Potentiometric Surface}

The potentiometric-surface map for the Tokio aquifer shows the altitude that water would have stood in tightly cased wells screened in the aquifer (fig. 9). Water-level measurements (table 2) in 50 wells during spring 2008 were used to construct the map. The surface was mapped by determining the altitude of the water levels and is represented on the map by contour lines that connect points of equal value. The general direction of groundwater flow is perpendicular to the contours in the direction of downward hydraulic gradient.

In the southwestern area, the direction of groundwater flow in the Tokio aquifer generally is towards the south or southeast. The potentiometric-surface high is within the outcrop area in the northwestern part of the southwestern area. The highest water-level altitude measured was $488 \mathrm{ft}$ above NGVD of 1929 in the outcrop area of Howard County. The lowest water-level altitude measured was $129 \mathrm{ft}$ above NGVD of 1929 about 5 mi northwest of Hope in Hempstead County. 


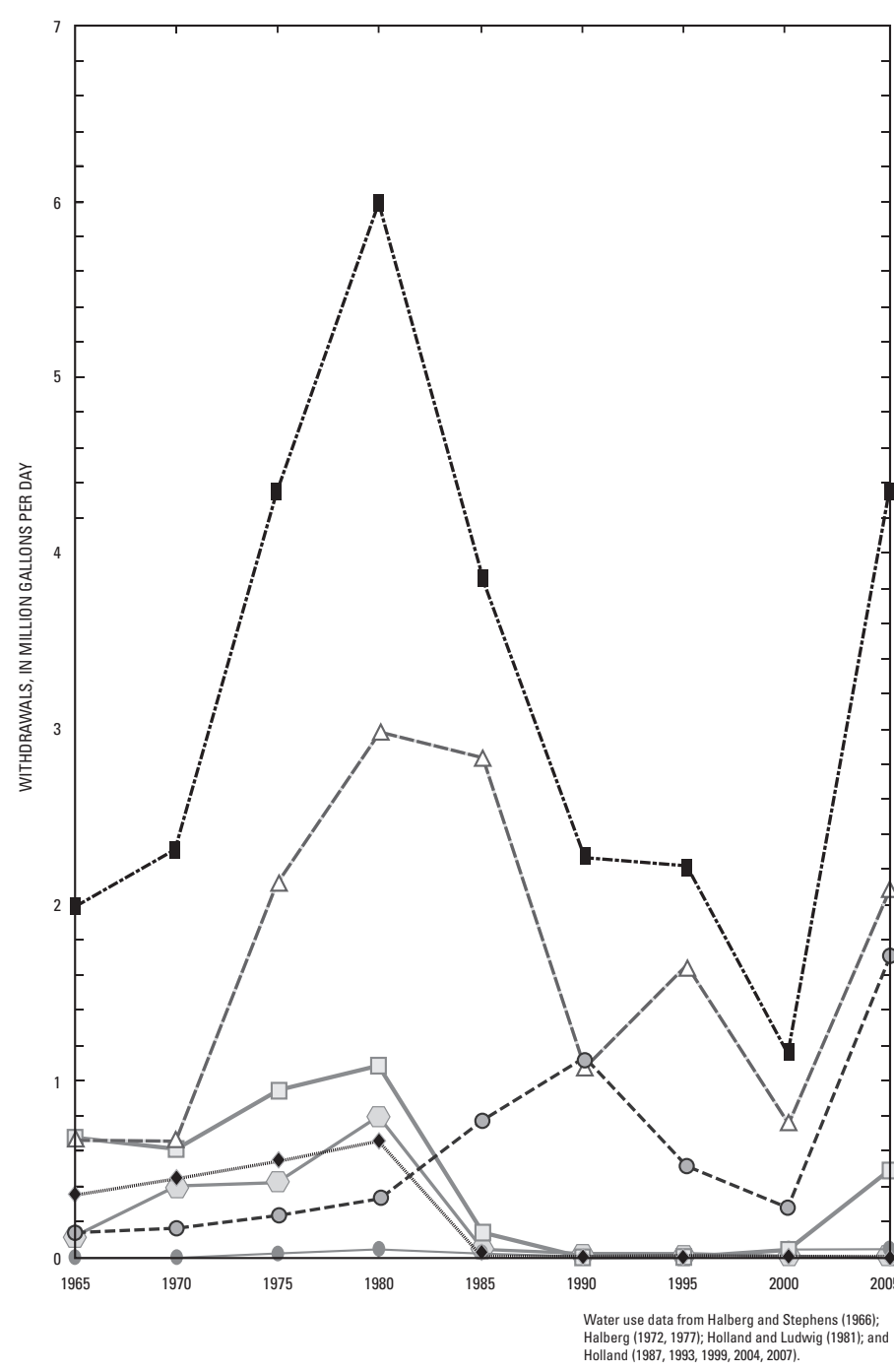

$$
\begin{aligned}
& \text { EXPLANATION } \\
& -- \text { Clark County } \\
& -\triangle-\text { Hempstead County } \\
& -\square-\text { Howard County } \\
& -\square \text { Nevada County } \\
& -\square-\text { Pike County } \\
& - \text { - Sevier County } \\
& --- \text { - Total Tokio aquifer }
\end{aligned}
$$

Figure 8. Withdrawals for the Tokio aquifer for the southwestern area in Arkansas.

An area of artesian flow exists in southeastern Pike, northeastern Hempstead, and northwestern Nevada Counties as evidenced by eight flowing artesian wells (fig. 9).

A cone of depression may exist about $5 \mathrm{mi}$ northwest of Hope. The northern half of an apparent cone of depression northwest of Hope is shown on figure 9. Water-level data in the Tokio aquifer were not available south of this area. No other cones of depression were evident in the Tokio aquifer. A comparison of the 2008 map with the 2002 and 1999 potentiometric-surface maps for the Tokio aquifer shows one substantial change; the 300-foot contour is positioned further north in Howard County. The change in this contour is the result of the addition of the measurement at well 10S27W02ACD1, which had not been collected prior to 2005 .

\section{Long-Term Water-Level Changes}

Four hydrographs from wells completed in the Tokio aquifer have long-term (minimum of 20 years) water-level altitudes (fig. 10). Two wells are located in Hempstead County (sites $\mathrm{G}$ and $\mathrm{H}$ ) and the other two wells are located in Howard (site I) and Nevada (site J) Counties (fig. 9). The minimum 20-year period is used to decrease the effect of short-term variations in climate and localized pumping rates on water levels in a single well.

The two hydrographs in Hempstead County show differences between water-level trends over long periods. In well 09S23W33CDA1 (site G, figs. 9 and 10), water levels generally declined from 1958 to 2008 . Water levels in well 12S24W06DAD1 (site H, figs. 9 and 10) fluctuated through a range in altitude of about 276 to about $132 \mathrm{ft}$ over a 37-year period. Water levels generally declined from 1971 to 1979 , generally rose from 1979 to 1989 , then declined from 1989 to 1999 . The average annual decline in water level at well 12S24W06DAD1 from 1971 to 2008 was $3.8 \mathrm{ft} / \mathrm{yr}$. Water withdrawals in Hempstead County increased from $0.67 \mathrm{Mgal} / \mathrm{d}$ in 1965 to $3.0 \mathrm{Mgal} / \mathrm{d}$ in 1980 , then decreased to $0.76 \mathrm{Mgal} / \mathrm{d}$ in 2000 . Water withdrawn increased to $2.10 \mathrm{Mgal} / \mathrm{d}$ in 2005 . The decline and rise in water levels in well 12S24W06DAD1 may be associated with the fluctuating withdrawals from the Tokio aquifer in Hempstead County, whereas water levels in well 09S23W33CDA1 do not appear to have a similar association. 


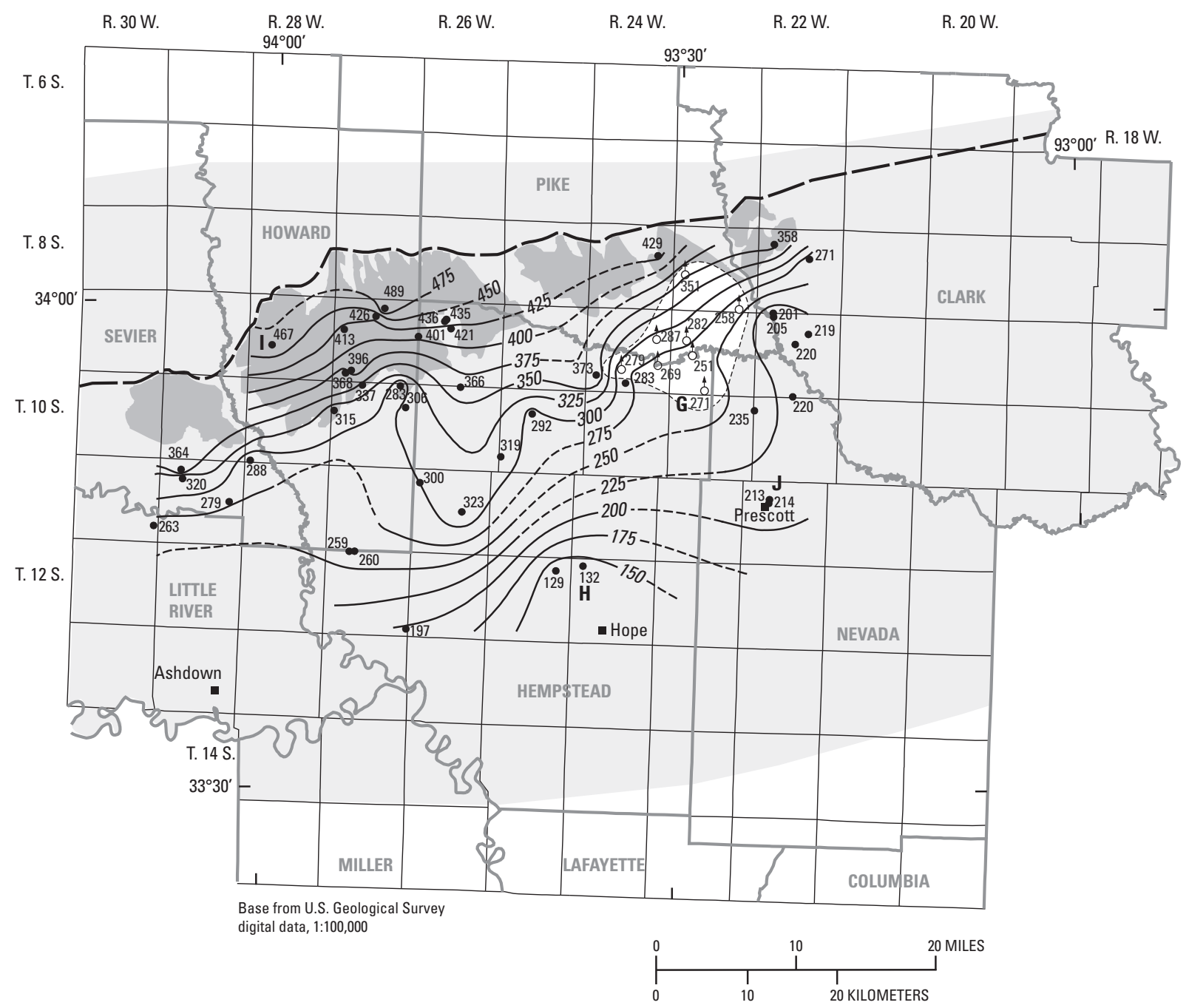

\section{EXPLANATION}

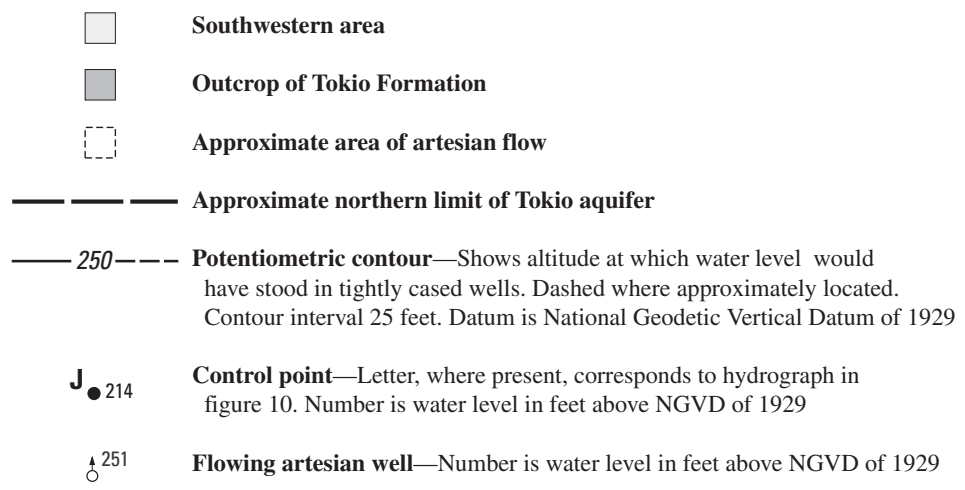

Figure 9. Potentiometric surface of the Tokio aquifer, southwestern Arkansas, spring 2008. 
Table 2. Water-level data collected during spring 2008 from wells completed in the Tokio Formation.

[NGVD of 1929, National Geodetic Vertical Datum of 1929; Horizontal datum is North American Datum of 1983; a negative depth to water indicates a flowing artesian well]

\begin{tabular}{|c|c|c|c|c|c|c|}
\hline Station name & $\begin{array}{c}\text { Latitude } \\
\text { (degrees, min- } \\
\text { utes, seconds) }\end{array}$ & $\begin{array}{c}\text { Longitude } \\
\text { (degrees, min- } \\
\text { utes, seconds) }\end{array}$ & $\begin{array}{c}\text { Water-level } \\
\text { altitude } \\
\text { (feet above } \\
\text { NGVD of 1929) }\end{array}$ & $\begin{array}{l}\text { Depth to water } \\
\text { (feet below } \\
\text { land surface) }\end{array}$ & $\begin{array}{c}\text { Land-surface } \\
\text { datum } \\
\text { (feet above } \\
\text { NGVD of 1929) }\end{array}$ & $\begin{array}{c}\text { Date of } \\
\text { measurement }\end{array}$ \\
\hline \multicolumn{7}{|c|}{ Clark County } \\
\hline 08S22W05CCC1 & 340408 & 932256 & 358 & 31.63 & 390 & $2 / 27 / 2008$ \\
\hline 08S22W15ABB2 & 340313 & 932018 & 271 & 53.59 & 325 & $2 / 27 / 2008$ \\
\hline 09S22W05BBB1 & 335951 & 932259 & 205 & 107.18 & 312 & $2 / 28 / 2008$ \\
\hline 09S22W05BCA1 & 335936 & 932257 & 201 & 33.60 & 235 & $2 / 28 / 2008$ \\
\hline 09S22W10DBA1 & 335832 & 932022 & 219 & 142.93 & 362 & $2 / 27 / 2008$ \\
\hline 09S22W16ACA1 & 335754 & 932120 & 220 & 13.23 & 233 & $2 / 27 / 2008$ \\
\hline \multicolumn{7}{|c|}{ Hempstead County } \\
\hline 09S23W20BDA1 & 335710 & 932859 & 251 & -1.23 & 250 & $2 / 21 / 2008$ \\
\hline 09S23W33CDA1 & 335457 & 932802 & 271 & -0.95 & 270 & $2 / 21 / 2008$ \\
\hline 09S24W25BBB1 & 335633 & 933132 & 269 & -0.50 & 268 & $2 / 21 / 2008$ \\
\hline 09S24W28ACC1 & 335617 & 933415 & 279 & -2.11 & 277 & $2 / 21 / 2008$ \\
\hline 09S24W30DCC1 & 335556 & 933607 & 373 & 17.04 & 390 & $2 / 21 / 2008$ \\
\hline 09S24W33ADC1 & 335526 & 933356 & 283 & 45.87 & 329 & $2 / 21 / 2008$ \\
\hline 09S26W08ADA2 & 335920 & 934717 & 435 & 2.53 & 438 & $2 / 21 / 2008$ \\
\hline 09S26W08ADD1 & 335918 & 934717 & 436 & 0.73 & 437 & $2 / 21 / 2008$ \\
\hline 09S26W09CDC1 & 335846 & 934656 & 421 & 3.89 & 425 & $2 / 21 / 2008$ \\
\hline 09S26W18CBB1 & 335815 & 934921 & 401 & 23.54 & 425 & $2 / 21 / 2008$ \\
\hline 10S25W09CDB1 & 335329 & 934052 & 292 & 69.48 & 361 & $2 / 21 / 2008$ \\
\hline 10S25W30CCD1 & 335048 & 934310 & 319 & 69.32 & 388 & $2 / 21 / 2008$ \\
\hline 10S26W03BBA1 & 335507 & 934612 & 366 & 1.18 & 367 & $2 / 25 / 2008$ \\
\hline 11S26W08BBB1 & 334909 & 934903 & 300 & 71.58 & 372 & $2 / 25 / 2008$ \\
\hline 11S26W23BBB1 & 334720 & 934602 & 323 & 95.74 & 419 & $2 / 25 / 2008$ \\
\hline 12S24W06DAD1 & 334360 & 933701 & 132 & 222.56 & 355 & $2 / 25 / 2008$ \\
\hline 12S25W02DDD1 & 334341 & 933902 & 129 & 237.92 & 367 & $2 / 22 / 2008$ \\
\hline 12S27W04BBC1 & 334450 & 935358 & 260 & 174.83 & 435 & $2 / 25 / 2008$ \\
\hline 12S27W05AAC1 & 334449 & 935421 & 259 & 176.22 & 435 & $2 / 25 / 2008$ \\
\hline 12S27W36DBC1 & 333958 & 935024 & 197 & 63.61 & 261 & $2 / 21 / 2008$ \\
\hline \multicolumn{7}{|c|}{ Howard County } \\
\hline 09S27W03DBD1 & 340000 & 935153 & 488 & 73.52 & 562 & $2 / 20 / 2008$ \\
\hline 09S27W10BCB1 & 335930 & 935232 & 426 & 108.06 & 534 & $2 / 20 / 2008$ \\
\hline 09S27W18ADB1 & 335840 & 935453 & 413 & 78.62 & 492 & $2 / 20 / 2008$ \\
\hline 09S27W32BDB1 & 335606 & 935424 & 396 & 54.57 & 451 & $2 / 20 / 2008$ \\
\hline 09S27W32BDB2 & 335606 & 935424 & 368 & 81.58 & 450 & $2 / 20 / 2008$ \\
\hline 09S28W20DAC1 & 335740 & 940014 & 467 & 12.64 & 480 & $2 / 20 / 2008$ \\
\hline 10S27W02ACD1 & 335454 & 935056 & 283 & 75.49 & 358 & $2 / 20 / 2008$ \\
\hline 10S27W04BBD1 & 335512 & 935330 & 337 & 55.48 & 392 & $2 / 20 / 2008$ \\
\hline 10S27W12CAB1 & 335356 & 935021 & 306 & 76.98 & 383 & $2 / 20 / 2008$ \\
\hline 10S27W18BAC1 & 335336 & 935535 & 315 & 106.87 & 422 & $2 / 20 / 2008$ \\
\hline
\end{tabular}


Table 2. Water-level data collected during spring 2008 from wells completed in the Tokio Formation.-Continued

[NGVD of 1929, National Geodetic Vertical Datum of 1929; Horizontal datum is North American Datum of 1983; a negative depth to water indicates a flowing artesian well]

\begin{tabular}{|c|c|c|c|c|c|c|}
\hline Station name & $\begin{array}{l}\text { Latitude } \\
\text { (degrees, min- } \\
\text { utes, seconds) }\end{array}$ & $\begin{array}{c}\text { Longitude } \\
\text { (degrees, min- } \\
\text { utes, seconds) }\end{array}$ & $\begin{array}{c}\text { Water-level } \\
\text { altitude } \\
\text { (feet above } \\
\text { NGVD of 1929) }\end{array}$ & $\begin{array}{l}\text { Depth to water } \\
\text { (feet below } \\
\text { land surface) }\end{array}$ & $\begin{array}{c}\text { Land-surface } \\
\text { datum } \\
\text { (feet above } \\
\text { NGVD of 1929) }\end{array}$ & $\begin{array}{c}\text { Date of } \\
\text { measurement }\end{array}$ \\
\hline \multicolumn{7}{|c|}{ Little River County } \\
\hline 11S30W25DDC1 & 334618 & 940852 & 263 & 22.16 & 285 & $2 / 19 / 2008$ \\
\hline \multicolumn{7}{|c|}{ Nevada County } \\
\hline 09S22W33DCC1 & 335437 & 932130 & 220 & 5.47 & 225 & $2 / 26 / 2008$ \\
\hline 10S23W12AAA1 & 335345 & 932421 & 235 & 21.14 & 256 & $2 / 26 / 2008$ \\
\hline 11S22W08DAC1 & 334758 & 932315 & 213 & 92.17 & 305 & $2 / 26 / 2008$ \\
\hline 11S22W08DAC8 & 334757 & 932312 & 214 & 91.47 & 305 & $2 / 26 / 2008$ \\
\hline \multicolumn{7}{|c|}{ Pike County } \\
\hline 08S23W19ADC1 & 340213 & 932931 & 351 & -1.01 & 350 & $2 / 20 / 2008$ \\
\hline 08S23W35DCA1 & 340004 & 932530 & 258 & -1.15 & 257 & $2 / 20 / 2008$ \\
\hline 08S24W14AAC1 & 340324 & 933134 & 429 & 94.41 & 523 & $2 / 20 / 2008$ \\
\hline 09S23W17BBC2 & 335804 & 932925 & 282 & -1.83 & 280 & $2 / 20 / 2008$ \\
\hline 09S24W14AAD1 & 335810 & 933139 & 287 & -1.63 & 285 & $2 / 20 / 2008$ \\
\hline \multicolumn{7}{|c|}{ Sevier County } \\
\hline 10S28W31DCC1 & 335026 & 940145 & 288 & 41.84 & 330 & $2 / 19 / 2008$ \\
\hline 11S29W05DCA1 & 334949 & 940653 & 364 & 116.33 & 480 & $2 / 19 / 2008$ \\
\hline 11S29W08DBB1 & 334907 & 940704 & 320 & 144.83 & 465 & $2 / 19 / 2008$ \\
\hline 11S29W13CCD1 & 334750 & 940317 & 279 & 81.42 & 360 & $2 / 19 / 2008$ \\
\hline
\end{tabular}




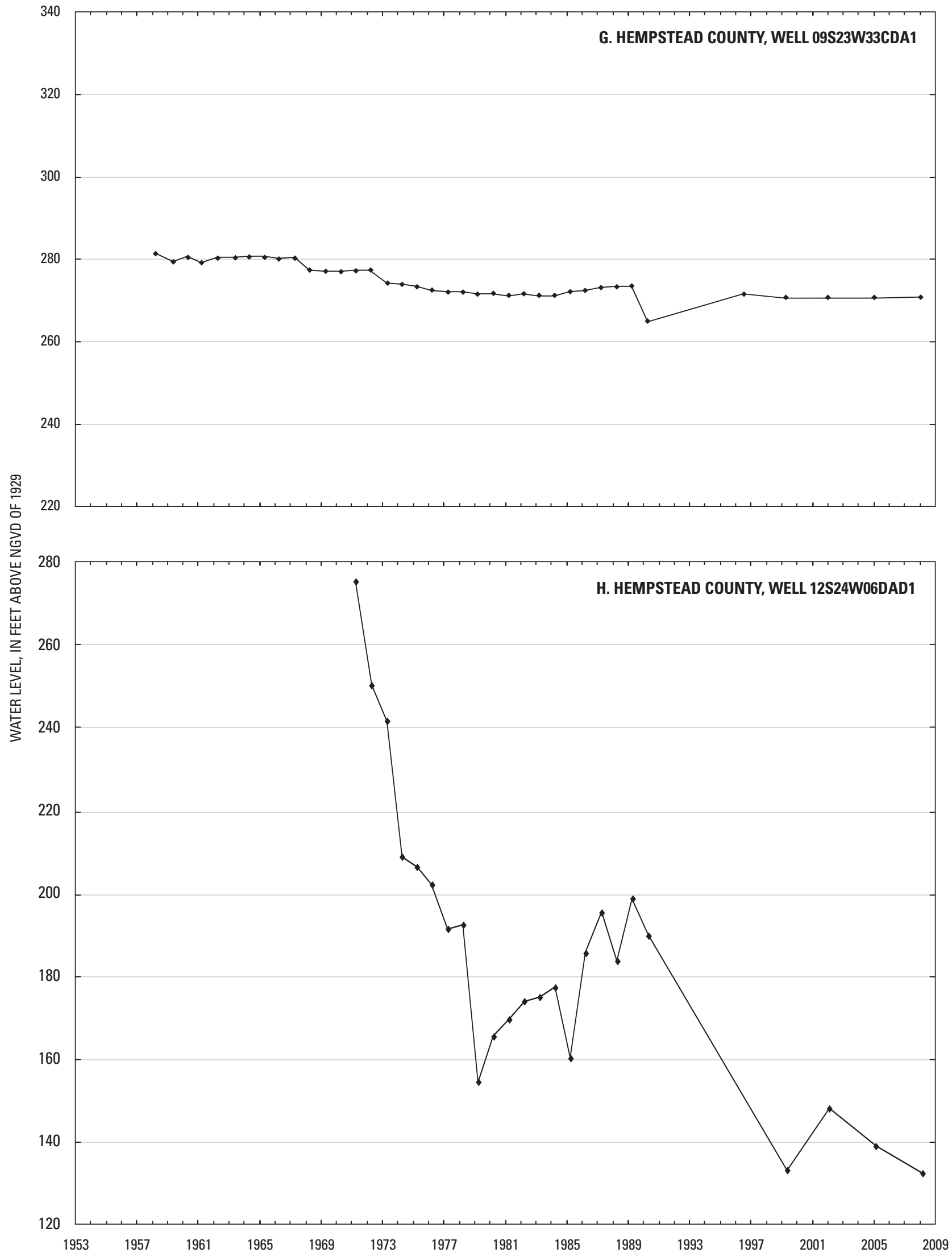

Figure 10. Water-level hydrographs for selected wells completed in the Tokio aquifer. 


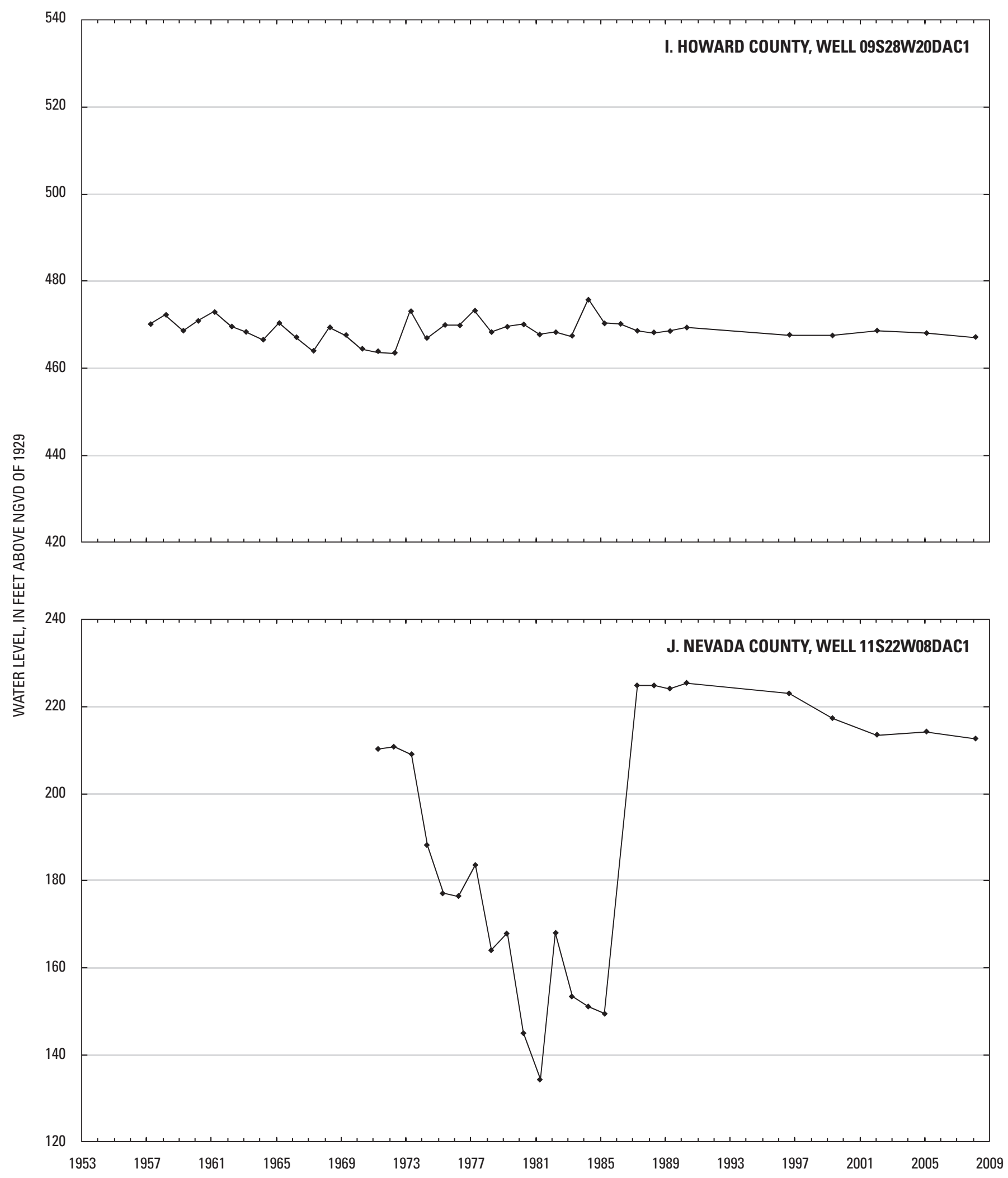

Figure 10. Water-level hydrographs for selected wells completed in the Tokio aquifer-Continued 
In Howard County, water levels in well 09S28W20DAC1 (site I, figs. 9 and 10) range from about $476 \mathrm{ft}$ to about $464 \mathrm{ft}$ over a 51-year period from 1957 to 2008. No substantial rises or declines in water levels were observed. In Howard County, water withdrawals were $0.69 \mathrm{Mgal} / \mathrm{d}$ in 1965 , increasing to $1.11 \mathrm{Mgal} / \mathrm{d}$ in 1980 . Water withdrawals decreased to 0.14 $\mathrm{Mgal} / \mathrm{d}$ in 1985 and less than $0.1 \mathrm{Mgal} / \mathrm{d}$ in 1990, 1995, and 2000. In 2005, water withdrawals increased to $0.50 \mathrm{Mgal} / \mathrm{d}$ in Howard County. There does not appear to be any association between water levels in this well and withdrawals from the Tokio aquifer (fig. 8).

In Nevada County, water levels in well 11S22W08DAC1 (site J, figs. 9 and 10) declined from about $211 \mathrm{ft}$ in 1972 to about $150 \mathrm{ft}$ in 1985 , with a minimum of $135 \mathrm{ft}$ in 1981. This is an annual decline of about $4.7 \mathrm{ft} / \mathrm{yr}$. Water withdrawals from the Tokio aquifer for Nevada County increased from 0.37 Mgal/d in 1965 to $0.68 \mathrm{Mgal} / \mathrm{d}$ in 1980 (fig. 8). From 1985 to 1987 , a rise in water level to about $225 \mathrm{ft}$ was observed, which is an approximately $37.5 \mathrm{ft} / \mathrm{yr}$ rise. From 1998 to 2008, there was a decline in water level from about $225 \mathrm{ft}$ to about $213 \mathrm{ft}$, respectively. Water withdrawals from Nevada County decreased to less than $0.10 \mathrm{Mgal} / \mathrm{d}$ by 1985 and continued at this rate through 1990, 2000, and 2005. The decline and rise in water levels may be associated with the increased and decreased withdrawals from the Tokio aquifer.

Although water levels in these four wells may be associated with changes in water use, other factors also may affect water levels such as climatic variations or changes in leakage to and from overlying and underlying rock units.

\section{Summary}

Aquifers in the Nacatoch Sand and Tokio Formation in southwestern Arkansas and the Nacatoch Sand in northeastern Arkansas are sources of water for industrial, public supply, domestic, and agricultural uses. A study was conducted by the U.S. Geological Survey in cooperation with the Arkansas Natural Resources Commission and the Arkansas Geological Survey to provide potentiometric-surface maps and waterlevel hydrographs associated with aquifers in the Nacatoch Sand and Tokio Formation (hereafter referred to as the Nacatoch aquifer and Tokio aquifer, respectively) in southwestern Arkansas and the Nacatoch aquifer in northeastern Arkansas.

Potentiometric-surface maps were constructed from water-level measurements made in 61 wells completed in the Nacatoch Sand and 50 wells completed in the Tokio Formation during spring 2008. In northeastern Arkansas, withdrawals from the Nacatoch aquifer increased by 480 percent from 1965 to 2005. In southwestern Arkansas, withdrawals from the Nacatoch and Tokio aquifers increased by 125 percent and 201 percent, respectively, from 1965 to 1980 and decreased by 93 percent and 80 percent, respectively, from 1980 to 2000. Withdrawals from Nacatoch aquifer and Tokio aquifer increased by 690 percent and 291 percent, respectively, from 2000 to 2005.
The direction of groundwater flow in the northeastern area of the Nacatoch aquifer generally is towards the southeast. The highest water level measured is located in northern Clay County along the north and northwestern boundary of this area. The lowest water level measured is located in eastern Clay County.

The direction of groundwater flow in the southwestern area of the Nacatoch aquifer is towards the south-southeast in Little River, Miller, and Hempstead Counties and to the eastsoutheast in Nevada and Clark Counties. The highest water level measured is located in the outcrop area in north-central Hempstead County. A depression exists at Hope in Hempstead County. Small depressions exist in southern Clark County and northeastern Hempstead County.

In the northeastern area of the Nacatoch aquifer, water levels in two wells declined during a period of increased withdrawals from the Nacatoch aquifer. Water levels in these wells have an annual decline of about $1.2 \mathrm{ft} / \mathrm{yr}$. The Clay County well consistently showed declines in water level from 1965 to 1990 . These declines may be associated with increased withdrawals in Clay County during this period. However, water levels since 1998 have been relatively stable. Withdrawals in Clay County have decreased from $1.98 \mathrm{Mgal} / \mathrm{d}$ in 1990 to $0.97 \mathrm{Mgal} / \mathrm{d}$ in 2005. The Greene County well shows an overall decline from 1977 until 1990. Water levels have been relatively stable since then.

In the southwestern area of the Nacatoch aquifer, the sharp decrease in withdrawal rates is explained by public water supplies in the southwestern area converting to surface water and relying less on groundwater sources. Four wells with historical measurements are located in the southwestern area. Water levels in the Hempstead County well show a decline from 1975 to 1979, a general rise from 1979 to 1999, a sharp decrease from 1999 to 2002, and a small decrease from 2005 to 2008. These fluctuations in water level can be explained by changes in water use. Water levels in the Nevada County well show an increase from 1985 to 1990, an average rise of about $17.6 \mathrm{ft} / \mathrm{yr}$. This increase in water levels occurred when the withdrawal rates from the Nacatoch aquifer in Nevada County decreased from 1985 to 1990 . Water levels declined from 2005 to 2008. Water levels in the Clark and Miller County wells do not reflect the changes associated with water use. The variation in water levels in these six wells located in the northeastern and southwestern areas could result from differences in localized withdrawals, climatic variations, or leakage of water from overlying and underlying rock units.

The direction of groundwater flow in the Tokio aquifer generally is towards the south or southeast. The highest water level measured is located where the aquifer outcrops in the northwestern part of the study area. An area of artesian flow exists in southeastern Pike, northeastern Hempstead, and northwestern Nevada Counties. A cone of depression may exist about 5 miles northwest of Hope in Hempstead County.

The hydrographs of two of four wells completed in the Tokio aquifer showed a decline and a rise in water levels 
during a period of increased, then decreased withdrawals from the Tokio aquifer. Water levels in the two wells in Hempstead County show differences between water-level trends over long periods. In well 09S23W33CDA1, water levels generally declined from 1958 to 2008. Water levels in well 12S24W06DAD1 fluctuated over a 37-year period. Water levels generally declined from 1971 to 1979 , generally rose from 1979 to 1989, then declined from 1989 to 1999. The decline and rise in water levels in well 12S24W06DAD1 may be associated with the fluctuating withdrawals from the Tokio aquifer in Hempstead County, whereas water levels in well 09S23W33CDA1 do not appear to have a similar association. In the Howard County well there does not appear to be any association between water levels in this well and withdrawals from the Tokio aquifer. Water levels in the Nevada County well declined from 1972 to 1985 and rose from 1985 to 1987. The decline and rise in water levels may be associated with the increased and decreased withdrawals from the Tokio aquifer.

\section{Selected References}

Boswell, E.H., Moore, G.K., MacCary, L.M., and others, 1965, Cretaceous aquifers in the Mississippi Embayment: U.S. Geological Survey Professional Paper 448- C, 37 p.

Counts, H.B., Tait, D.B., Klein, Howard, and Billingsley, G.A., 1955, Ground-water resources in a part of southwestern Arkansas: U.S. Geological Survey Water Resources Circular No. 2, 35 p.

Fenneman, N.M., 1938, Physiography of western United States: New York, McGraw-Hill Book Co., Inc., 689 p.

Halberg, H.N., 1972, Use of water in Arkansas, 1970: Arkansas Geological Commission Water Resources Summary Number 7, $17 \mathrm{p}$.

Halberg, H.N., 1977, Use of water in Arkansas, 1975: Arkansas Geological Commission Water Resources Summary Number 9, $28 \mathrm{p}$.

Halberg, H.N. and Stephens, J.W., 1966, Use of water in Arkansas, 1965: Arkansas Geological Commission Water Resources Summary Number 5, 12 p.

Helsel, D.R., and Hirsch, R.M., 1992, Statistical methods in water resources: New York, NY, Elsevier Science Publishing Co., $522 \mathrm{p}$.
Holland, T.W., 2007, Estimated water use in Arkansas, 2005: U.S. Geological Survey Scientific Investigations Report 2004-5230, $31 \mathrm{p}$.

Holland, T.W., 2004, Estimated water use in Arkansas, 2000: U.S. Geological Survey Scientific Investigations Report 2007-5241, $32 \mathrm{p}$.

Holland, T.W., 1999, Water use in Arkansas, 1995: U.S. Geological Survey Open-File Report 99-188, 1 sheet.

Holland, T.W., 1993, Use of water in Arkansas, 1990: U.S. Geological Survey Open-File Report 93-48, pamphlet.

Holland, T.W., 1987, Use of water in Arkansas, 1985: Arkansas Geological Commission Water Resources Summary Number 16, $30 \mathrm{p}$.

Holland, T.W., and Ludwig, A.H., 1981, Use of water in Arkansas, 1980: Arkansas Geological Commission Water Resources Summary Number 14, 30 p.

Ludwig, A.H., 1972, Water resources of Hempstead, Lafayette, Little River, Miller, and Nevada Counties, Arkansas: U.S. Geological Survey Water-Supply Paper 1998, 41 p.

Payne, J.N., 1968, Hydrologic significance of the lithofacies of the Sparta Sand in Arkansas, Louisiana, Mississippi, and Texas: U.S. Geological Survey Professional Paper 569-A, $17 \mathrm{p}$.

Petersen, J.C., Broom, M.E., and Bush, W.V., 1985, Geohydrologic units of the Gulf Coastal Plain in Arkansas: U.S. Geological Survey Water-Resources Investigations Report 85-4116, $20 \mathrm{p}$.

Plebuch, R.O., and Hines, M.S., 1969, Water resources of Clark, Cleveland, and Dallas Counties, Arkansas: U.S. Geological Survey Water-Supply Paper 1879-A, 32 p.

Schrader. T.P., 2007, Status of water levels in aquifers in the Nacatoch Sand of southwestern and northeastern Arkansas and Tokio Formation of southwestern Arkansas, February 2005: U.S. Geological Survey Scientific Investigations Report 2007-5024, 21 p.

Schrader. T.P., and Scheiderer, R.M., 2004, Status of water levels in aquifers in the Nacatoch Sand of southwestern and northeastern Arkansas and Tokio Formation of southwestern Arkansas, 2002: U.S. Geological Survey Water- Resources Investigations Report 03-4284, $24 \mathrm{p}$. 
Publishing support provided by:

Lafayette Publishing Service Center

For more information concerning the research described in the report

U.S. Geological Survey

Arkansas Water Science Center

401 Hardin Road

Little Rock, AR 72211-3528

(501) 228-3600

http://ar.water.usgs.gov 

